\title{
1956 Süveyş Krizi ve Ortadoğu'ya Etkisi
}

\author{
Mehmet Erkan Kıllıŏlu*
}

(ORCID: 0000-0002-3146-2609)

Makale Gönderim Tarihi

22.05.2021
Makale Kabul Tarihi

25.09.2021

\section{Atıf Bilgisi/Reference Information}

Chicago: Kıllıoğlu, M. E., "1956 Süveyş Krizi ve Ortadoğu’ya Etkisi”, VakanüvisUluslararası Tarih Araştırmaları Dergisi, 6/2 (2021): 726-757.

APA: Kıllıoğlu, M. E. (2021). 1956 Süveyş Krizi ve Ortadoğu'ya Etkisi. Vakanüvis-Uluslararası Tarih Araştırmaları Dergisi, 6 (2) , 726-757.

\section{Öz}

İkinci Dünya Savaşı sonrasındaki dönemde 19. yüzyılın büyük sömürge imparatorlukları ve onların kurmuş oldukları düzen dağılmış ve bir tarafta SSCB diğer taraf da ise ABD'nin önderliğini yaptığı iki kutuplu bir uluslararası siyasi yapı ortaya çıkmışır. Bu yeni yapının ortaya çıkması eski düzenin tasfiyesini de beraberinde getirmiştir. Bu tasfiye sürecinde İngiltere kendi iktisadi, siyasi ve askeri yapısına büyük yük bindiren sömürgelerini tahliye ve tasfiye etme yoluna gitmiştir. Ancak bunu yaparken stratejik açıdan önemli noktaları, en azından Süveyş Kanalı'nın batısında kalan bölgeler gibi stratejik açıdan önemli noktaları, elinde tutmaya çalışmıştır. Mısır topraklarında kalan Süveyş Kanalı bölgesi bu kilit önemdeki noktalardan biridir. Eski sömürge geçmişi sebebiyle Batı ile ilişkileri zaman zaman kötüleşen Mısır yine böyle sorunlu olaylardan birinin sonrasında Süveyş Kanalını devletleştirdiğini açıklamıştır. Bu karardan Batı Dünyası'nın lideri konumundaki ABD memnun olmamış ancak SSCB'nin Ortadoğu'ya müdahil olmasına ve etkisini attırmasına sebep olmaması için gerginliği

\footnotetext{
*Dr., Çanakkale Onsekiz Mart Üniversitesi, Türkiye, mehmeterkan@comu.edu.tr. PhD., Çanakkale Onsekiz Mart University, Turkey.
}

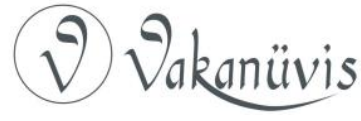


büyütmemeye çalışmıştır. Ancak Kanal'ın idaresini ellerinde tutan Ingiltere ve Fransa bu durumdan rahatsız olmuş, hem Kanalı geri almak hem de kendilerine Ortadoğu bölgesinde düşmanlık yapan Mısır lideri Cemal Abdünnasır'ı devirmek için harekete geçmeye karar vermişlerdir. Bunun sonucunda da 1956 Süveyş Krizi yaşanmıştır. Ingiltere ve Fransa askeri mücadeleyi kazanmıştır ancak siyasi mücadeleyi kaybetmiştir. Bunun sonucunda Ortadoğu bölgesinde ve dünya sisteminde dengeler değişmiştir. Süveyş Krizi de bu değişimin başlangıç noktası olmuştur.

Anahtar Kelimeler: Süveyş Krizi, Cemal Abdünnasır, Anthony Eden, Eisenhower, John Foster Dulles, Silahşör (Muskeeter) Operasyonu.

\section{Suez Crisis 1956 and Consequences to the Middle East}

\section{Abstract}

In the period after the Second World War, the great colonial empires of the 19th century and their colonial order fade away and a new bipolar international political system led by the USA and USSR, emerged. The emergence of this new international political system forced the disintegration of the old order. During this disintegration process, Britain tried to evacuate and liquidate her former colonies, which put a huge burden on its economic, political and military system, but in doing so tried to keep the strategically important points, at least the ones left in the west of the Suez Canal. The Suez Canal region, which remained in Egyptian territory, was one of those strategic assets. Egypt, whose relations with the West occasionally deteriorated due to its former colonial past history, announced that it had nationalized the Suez Canal after one of such problematic events. Although the USA, the presumed leader of the Western World, was not satisfied with that decision, but tried to decrease the tension in order to cease the USSR intervention to the Middle East and increase its influence. However, Britain and France, who are in charge of the Suez Canal and Canal Company, were not satisfied with Egypt's decision that nationalized the Suez Company. They took decisive action both to take the Canal back and to overthrow the Egyptian leader Gamal Abdünnasir, who was hostile to them in the Middle East region. As a result, the Suez Crisis of 1956 occurred. Britain and France

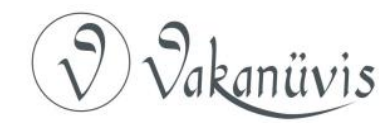


won the military struggle but lost in the political process. Balances in the Middle East region and the world system have changed dramatically and the Suez Crisis was the starting point of this change.

Keywords: Suez Crisis, Gamal Abdunnasir, Athony Eden, Eisenhower, John Foster Dulles, Opearation Muskeeter.

\section{Giriş}

İkinci Dünya Savaşı sonrasında ortaya çıkan iki kutuplu dünya düzeni ve Soğuk Savaş dünyayı bu yeni döneme göre şekillendirmiştir. $\mathrm{Bu}$ durumun ve değişimin elbette Ortadoğu'ya da yansımaları olmuştur. 1948 yılında İsrail'in bu coğrafyada bir uluslararası aktör olarak ortaya çıkması Soğuk Savaş'ın Ortadoğu'ya taşınmasını da beraberinde getirmiştir. Batı dünyası ile rekabet halinde olan Sovyetler Birliği Ortadoğu'da etkin olmasını sağlayacak fırsatlar aramış, bu kapsamda da ilk başlarda İsrail'le yakınlaşmayı denemiştir. Ancak daha sonra bölgede azınlık bir grup olan Yahudiler yerine onlarla ve bu bölgede 19. yüzyıldan itibaren sömürge yönetimleri kurması nedeniyle Batı Dünyası ile istikrarlı bir ilişkisi olmayan Arap Dünyası ile yakınlaşmayı daha uygun bulmuştur. Bu kapsamda Sovyetler Birliği, Arap ülkeleri arasında adı ön plana çıkan Mısır ve Suriye gibi devletlerle iyi ilişkiler kurulmasına özel önem vermeye başlamıştır.

Yeni kurulan uluslararası sistem sebebiyle 19. yüzyıldan beri Ortadoğu'da etkili olan İngiliz ve Fransız sömürge imparatorluklarının gücü eskiye nazaran belirgin bir şekilde azalmaya başlamıştır. Özellikle Ingiltere, Soğuk Savaş adı verilen bu yeni döneme ve onun şartlarına uymak için kendi idari, askeri ve ekonomik yapısı üzerinde ciddi bir mali külfet haline gelen sömürgelerinden çekilmeyi en uygun çözüm olarak görmüştür. Ancak sömürge yönetimini tasfiye ederken dünya üzerindeki kilit önemdeki noktaları da terk etmeyi planlamamıştır. Ingiltere'nin kontrolü altında kalmasını planladığı bu stratejik noktalardan biri de Süveyş Kanalı bölgesi olmuştur. İngiltere, Süveyş Kanalı'nı elinde tutarak Akdeniz'deki gücünü korumak ve etkisini 
devam ettirmek istemiştir. Ancak Mısır, yabancı güçlerin idaresinde kaldığı dönemi hatırlattığı için bu duruma şiddetle karşı çıkmıştır. ${ }^{1}$

İngiliz stratejisi açısından bakılacak olursa Süveyş Kanalı, Kıbrıs, Malta ve Cebelitarık şeklinde uzanan ve Akdeniz'i ve önemli deniz ticaret yollarından birini kontrol eden stratejik zincirin ilk halkası ve başlangıç noktasıdır. Süveyş Kanalı hariç, İngiltere'nin bu sayılan noktalarda halen mevcudiyetini devam ettirdiğini de unutmamak gerekir. İngiltere'nin Süveyş'teki kontrolünü devam ettirme isteği bağımsızığını ispat etmek için görünür semboller arayan Mısır’ın kendi toprakları üzerindeki hâkimiyet ve egemenlik iddiası ile çatışınca 1956 yılında Süveyş Krizi olarak tarihe geçecek olan olaylar dizisinin de temeli atılmıştır.

İşte bu çalışmada Süveyş Krizi'nin ortaya çıkışı, sebepleri, gelişimi ve Ortadoğu ve Türkiye açısından sonuçlarına incelenecektir. ABD'nin ve Sovyetlerin bu duruma nasıl yaklaştıkları ve onları harekete geçmeye mecbur bırakan sebeplere de değinilecektir. Konunun Türkiye ile ilgili kısmına gelince; Türkiye'nin bu krize olan tepkisi veya Bağdat Paktı'na üye olması sebebiyle Pakt'ın üyelerinden olup Mısır'a karşı askeri harekâta girişen İngiltere'ye karşı olan kısmi tepkisizliği, bu tutumuna İsrail'le olan ilişkisi de eklenince bu durumunun Arap Dünyasında nasıl anlaşıldığı da tartışılacaktır. Bu sorulara ek olarak ortaya çıkan bir gerçek ise Arap Dünyası'nın Türkiye'nin İsrail'i tanıması ve bu krizde Sovyet tehdidini İngiltere ile dengeleme isteği yüzünden tarafsız kalma çabasını yanlış anladığı veya anlamak istediğidir. Bu duruma karşılık vermek için Arap ülkeleri Kıbrıs konusunda kasıtlı olarak Türkiye'nin karşısında yer almıştır. Buna Bağdat Paktı́nda müttefiklik ilişkisi tesis ettiği Irak da dâhildir. Bu tutumlar taraflar arasında bir güvenlik ikilemini tetiklemiştir. Türkiye bu sarmalı kırmak ve Arap Dünyası'na yakınlaşmak için 1960'lı yıllarda bir dizi girişimde bulunmuş ama bu girişimlerden beklediği karşılığı görmemiştir. Bu sayılan konulara değinilecek olan çalışma 5 kısımda kurgulanmıştır.

Süveyş Krizi'ne siyasi tarih-uluslararası ilişkiler perspektifinden yaklaşarak açıklamayı ve bu konudaki bilgi kaynağını genişletmeyi

1 Sabit Duman, Ortadoğu Krizleri ve Türkiye, Ankara Üniversitesi Türk Inkilap Tarihi Enstitüsü Atatürk Yolu Dergisi, Sayı: 35-36, (2005), s. 314.

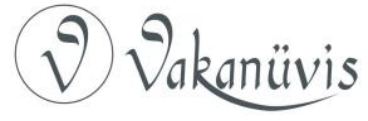


amaçlayan çalışmada literatür taraması kapsamında İngilizce ve Türkçe birincil ve ikincil kaynaklar; bu konuda kaleme alınmıs olan kitap ve makaleler taranmış, dönemi yaşayan resmi görevlilerin anıları ve hatıratları incelenmiştir. Konu ile ilgili ortaya çıkan yeni kaynakların kullanılarak Süveyş Krizi konusunda daha kapsamlı analiz yapmak ve bu bilgilerin yardımıyla Ortadoğu ile ilgili yapılacak olan çalışmalara perspektif ve yaklaşım desteği sağlamak çalışmadan beklenen faydalar arasındadır. Devletlerin hafızaları, olaylara karşı tutum ve tavırlarının kaynağı geçmişte yaşadıkları olaylardır. Bu yüzden bunları hatırlamak ve analiz etmek mevcut şartlarda nasıl hareket edeceklerini tahmin etmede bize perspektif sağlayacaktır.

\section{Krizi'nin Ortaya Çıkışı ve Gelişimi}

II. Dünya Savaşı'nın sona ermesinden sonra, Soğuk Savaş sonucu ortaya çıkan kutuplaşmaya Ortadoğu ülkelerinin de dâhil olması üzerine, Ortadoğu bölgesi de gerginliklerin odağı olmaya başlamıştır. Bölgede gerginliklerin tırmanmasında pek çok faktörün etkisi vardır ama bunlar içinde en önemli olanı Araplar ile İsrail arasındaki çatışmadır. 1950'de ABD, Fransa ve İngiltere İsrail'le Arap komşularını ayıran 1947 tarihli ateşkes hattının ihlal edilmemesini öngören Üçlü Deklarasyon'u (Tripartite Declaration) yayınlamıştır. Bu deklarasyonun bölgedeki gerginliklerin azalmasına bir faydası olmamış ve işlevsiz kalmıştır. Buna rağmen Amerika Birleşik Devletleri'nin (ABD) Ortadoğu politikasının önemli bileşenlerinden birisi olmuştur.

Ortadoğu bölgesinde gerginliklerin sürdüğü bu siyasi ortamda, 1955 yılı sonbaharında Sovyet Sosyalist Cumhuriyetler Birliği (SSCB), Mısır'dan gelen talep üzerine, bu ülkeye silah satışı yapılmasını öngören bir anlaşmaya onay vermiştir. ${ }^{2}$ Bu anlaşma ile Mısır 1955 yılının sonlarında (Eylül ayında) Sovyetler Birliği'nden yeni silahlar almıştır. Bu silah satışı sayesinde Sovyetler Ortadoğu'da etkililerini arttırabilmeleri için aradıkları fırsatı ele geçirmiştir. ${ }^{3}$ Bunun üzerine

\footnotetext{
2 Peter L. Hahn, The Suez Crisis, A Crisis That Changed the Balance of Power in the Middle East, Significant Events in U. S. Foreign Relations, 1900-2001, Foreign Policy Agenda, ejournalusa, U. S. Department of State/Bureau of International Informations Programs, Cilt: 11, Sayı: 1,(Nisan 2006) Washington, s. 27.

${ }^{3}$ Larry Hart, "Failures in American Diplomacy: The Suez Crisis, 1956", History Studies, Cilt: 3, ABD ve Büyük Ortadoğu ilişkileri Özel Sayısı 2011, s. 158.
}

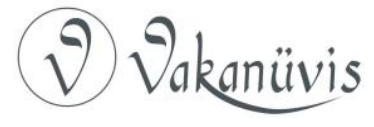


İsrail, Cemal Abdünnasır'ın siyasi kariyerini zora sokacak ve Sovyet silahları ile güçlü bir ordu kurmadan önce askeri gücünü yok edecek baskın bir saldırı yapılması konusunda İngiltere ve Fransa'ya baskı yapmaya başlamıştır. ${ }^{4}$ Mısır, silah tedariki için SSCB başvurmuştur çünkü o dönemde ABD Mısır'a silah satışını şarta bağlamıştır. ABD yönetimi satılacak olan silahların sadece Amerikalı askeri danışmanlar tarafından kullanıımasını şart koşmuştur. $A B D$, ancak bu şartın kabulü halinde silah satışına onay vereceğini Mısır'a bildirmiştir. Bu şartlı kullanım taahhüdü ile Eisenhower, Amerikan silahlarının olası bir krizde İsrail'e karşı kullanımını önlemeyi amaçladığı açıktır. ${ }^{5}$ Mısır, $A B D$ nnin öne sürdüğü bu şartı kabul etmemiştir. $A B D$ yönetimi de silah satışına onay vermemiştir. Dönemin ABD Dışişleri Bakanı John Foster Dulles'ın, Nasır'a karşı olan olumsuz bakış açısının da silah satış anlaşmasının sonuçsuz kalmasında etkisi olmuştur. ${ }^{6}$ Ancak daha sonra Dulles, Nasır'a istediği silahların verilmemesinin büyük bir hata olduğunu ifade edecektir. ${ }^{7}$ Bundan sonra da Mısır'ın ABD ve Batı ile olan ilişkileri hızla kötüleşmeye başlamıştır.

Göreve geldiği ilk yıllardan itibaren ekonomik açıdan Mısır'ı kalkındırılmaya çalışan Nasır, bu amaçla Nil ırmağı üzerinde bir baraj inşa edilmesini için çalışmaya başlamıştır. Asvan Barajı adı verilen ve elektrik üretim ve tarım alanlarının sulanmasında kullanılması planlanan bu barajın yapılabilmesi için ekonomik yardıma ihtiyaç olmuştur. Çünkü oldukça büyük ve kapsamlı bir imalat işi gerektiren bu projenin hayata geçirilmesinde Mısır'ın kendi iç kaynakları yeterli değildir. Bu yüzden büyük miktarda kredi ve yabancı sermayeye ihtiyaç duyulmuştur. ${ }^{8}$ Bozulan ilişkileri düzeltebilmek için $A B D$ yönetimi

\footnotetext{
${ }^{4}$ Hahn, a.g.m. , s. 27.

${ }^{5}$ R. W. Rathburn, Operation Musketeer: A Military Success Ends in Political Failure, Marine Corps Command and Staff College, Marine Corps Development and Education Command, War Since 1945 Seminar, Quantico Virginia: 2 Nisan 1984, http://www.globalsecurity.org/military/library/report/1984/RRW.htm , (Erişim tarihi: 07.09.2018) Ayrıca bkz. Fahir Armaoğlu, Filistin Meselesi ve Arap Israil Savaşları 19481988, Ankara: Türkiye İş Bankası Kültür Yayınları, 1991, s. 128.

6 Hisham Sharabi, Goverments and Politics of the Middle East Twentieth Century, Princeton-New Jersey: D. Van Nostrand Company Inc. 1962, s. 215.

7 Hart, a.g.m., s. 159.

${ }^{8}$ Şevket Süreyya Aydemir, Asvan Barajı Problemi, Ortadoğu, Cilt: 1, Sayı: 4, (1961), s. 912.
}

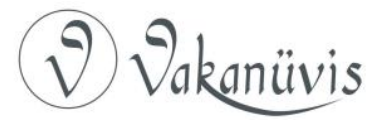


elinden geleni yapmış, Eisenhower ve Dulles, Mısır'ı tekrar Batı yörüngesine sokmak için çok çaba sarf etmiştir. Bu kapsamda ABD Dışişleri Bakanı J.F. Dulles Nasır'ın güvenini kazanmaya çalışmıştır. Bu girişimlerin sonucunda, aynı yılın sonunda $A B D$, İngiltere ve Dünya Bankası ile birlikte, Mısır'a Asvan Barajı'nın inşaatında kullanılmak üzere kredi vermeyi teklif etmiştir. ${ }^{9}$

Gerek ABD gerekse İngiltere, Asvan Barajı́nın yapımına finansman desteği sağlayarak Mısır'la olan ilişkilerini düzeltebileceklerini düşünmüşlerdir. Ancak baraja finansman temini için Nasır sadece Batı Dünyasına bağlı kalmayı istememiştir. ${ }^{10}$ Barajın finansmanı için Sovyetler Birliği ile de görüşmelerde bulunmuş ve Sovyetler Birliği'nden daha iyi bir öneri gelebilir umuduyla Batılı ülkeleri oyalamaya çalışmıştır. Nasır'ın bu baraj inşaatını finanse etmek için aynı zamanda Sovyetler Birliği ile görüştüğü haberi Batılı ülkelere ulaşmış ve bu durum Batı'da rahatsızlık yaratmıştır. ${ }^{11}$ Bu arada 1956 Mayıs'ında, Nasır'ın Tayvan'daki Çan-Kay-Şek rejimini tanımaktan vazgeçerek onun yerine Komünist Çin'i, Çin'in resmi varisi olarak tanıması Washington'da Nasır'a olan kızgınlığı arttırmıştır. ${ }^{12}$ Nasır'ın Komünist Çin'i tanımasının ardında yatan sebep, Batı Dünyasını kızdırmaktan ziyade, Sovyetler Birliği'ne karşı duyduğu güvensizliktir. Mısır, Sovyetler Birliği'nin de Mısır'a uygulanan silah ambargosuna katılma ihtimalini göz önünde tutarak Komünist Çin'i tanıma yoluna gitmiştir. Nasır, silah tedariki hususunda Sovyetler Birliği'nin de bir seçenek olmaktan çıkması halinde elinde bir alternatif olmasını istemiştir. ${ }^{13}$ Ancak kendisini ve rejimini güvence altına almak için yaptığı bu girişimler kendisine karşı duyulan güvensizliği arttırmaktan başka bir işe yaramamıştır. Yine ABD, Mısır ve Nasır'la ilgili duyduğu tüm memnuniyetsizliğe rağmen Haziran 1956'da, Asvan Barajı'nın

\footnotetext{
${ }^{9}$ Hart, a.g.m., s. 159.

10 "Silah temini konusunda olduğu gibi, kredi finansmanı konusunda da Nasır, öncellikle Batılı kaynaklara başvurmayı tercih etmiştir." Hart, a.g.m., s. 159.

11 Mehmet Gönlübol vd., Olaylarla Türk Dış Politikası (1919-1995), Ankara: Siyasal Kitabevi, 1996, s. 279.

12 Robert C. Grogin, Natural Enemies, The United States and the Soviet Union in the Cold War 1917-1991, Lenham-Maryland: Lexington Books, 2001, s. 192.

13 Peter Calvocoressi, World Politics since 1945, Londra: Longman Group UK Limited, 1987, s. 213.
}

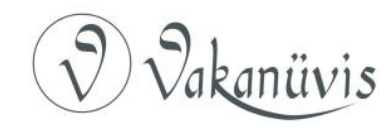


yapımı için gereksinim duyulan krediyi Mısır'a sağlayacağını resmen bildirmiştir. Ancak o dönemde Cemal Abdünnasır ve onun prestij sembolü olan barajı, ABD Kongresi'nde pek popüler değildir. Bunun sebebi de $A B D^{\prime} l i$ pamuk üreticileridir. Mısır'ın elektrik üretiminin artmasına büyük katkı sağlayacak olan Asvan Barajı ayrıca sulanabilen alanların da artmasına imkân sağlayacaktı. Bunun sonucunda ülkenin pamuk üretimi de artacaktır. Ancak Mısır'da ortaya çıkacak olan bu üretim artışı uluslararası piyasalarda pamuk bolluğuna yol açacak, bunun sonucunda da pamuk fiyatları düşecektir. Tüm bunların nihai sonucu ise önemli bir gelir kaybı olacaktı. Bu yüzden ABD'li Güneyli pamuk üreticileri Mısır'ın baraj inşaatına finansman teminine karşı çıkmıştır. ${ }^{14}$ ABD Kongresi'ndeki pek çok temsilci de bu görüşü paylaşmıştır. ${ }^{15}$ Bu yüzden Amerikan Senatosu kendi izni olmadan Asvan Barajı için herhangi bir kredi açılmaması kararını almış ve yardımı durdurmuştur. ${ }^{16}$ Bunun üzerine ABD yönetimi de 19 Temmuz 1956'da kredi önerisi geri çekmiştir. ${ }^{17}$ Bunu İngiltere ve Fransa'nın Mısır’a olan tüm mali desteklerini ve yardım önerilerini geri çekmesi takip etmiştir. Çünkü 1956 yılı başlarında Amerikalılar ve İngilizler her geçen gün SSCB ile ilişkilerini geliştiren ve Sovyetler'e Ortadoğu'da etkin rol oynama fırsatı veren Mısır lideri Nasır'ı bir dizi siyasi ve iktisadi önlemlerle önce izole etmek ve terbiye etmek, bu durumdan gereken dersi çıkaramazsa da devirmek için anlaşmıştır. Nasır'ı devirmeyi öngören bu plana "Omega Operasyonu" adı verilmiştir. ${ }^{18}$ Sırasıyla ABD, İngiltere ve Fransa'nın aldığı bu kararlardan bir hafta sonra, 26 Temmuz'da Nasır,

\footnotetext{
${ }^{14}$ Lewis Gaddis, We Now Know: Rethinking Coldwar History, New York: Oxford University Press, 1997, s. 171.

“ABD Kongresi içinde Mısır'ın Asvan Barajı́nın finansmanına olumsuz tutum takınımasındaki sebeplerin en önemlileri arasında $A B D^{\prime} l i$ pamuk üreticilerinin temsilcilerinin bu duruma muhalif tutumları gelmekteydi. ABD'li üreticiler, Mısır'da sulama imkânlarının artması halinde, dış pazarlarda Mısır pamuğunun Amerikan pamuğuyla rekabet etmeye başlayacağını düşünüyorlardı ve bu durumu istemiyorlardı." Calvocoressi, a.g.e., s. 223.

${ }^{15}$ Hart, a.g.m. , s. 159.

16 Fahir Armaoğlu, 20 Yüzyıl Siyasi Tarihi 1914-1980, Ankara: Türkiye İş Bankası Kültür Yayınları, 1983, s. 498.

17 “19 Temmuz'da Dulles, Mısır Dışişleri Bakanı'nı arayarak ABD’nin Asvan Barajı'nın inşaatına finansman sağlamayacağının bilgisini vermiştir." Hart, a.g.m. , s. 159.

${ }^{18}$ Hahn, a.g.m. , s. 27.
}

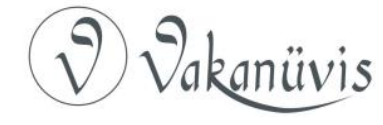


Süveyş Kanalı' nı millileştirdiğini ilan etmiştir. ${ }^{19}$ Bundan sonra da Süveyş Krizi patlak vermiştir. ${ }^{20}$ Krizin sebebi temelde Temmuz 1956 ' da Nasır'ın istediği ekonomik yardımın İngiltere ve $A B D$ tarafından reddedilmesidir. Nasır, bu ret cevabına karşılık olarak Süveyş Kanal Şirketi'ni devletleştirme yoluna gitmiştir. ${ }^{21} 1956$ yılındaki Süveyş Kanalı'nın devletleştirilmesi aslında tamamıyla Nasır'ın Ulusçuluk söyleminin ikinci adımının hayata geçirilmesinden ibarettir. ${ }^{22}$

$\mathrm{Bu}$ tasarrufu ile Nasır, Avrupalı sömürgeci devletlerden korkmadığını göstermeyi ve özellikle Üçüncü Dünya'da olan desteğini ve popülerliğini arttırmayı amaçlamıştır. ${ }^{23}$ Batılı devletlerden bağımsız hareket edebileceğini göstermek ve onların prestijlerini kırmak için de Kanal'a ve Kanalı yöneten İngiliz-Fransız ortak şirketine elkoyma yoluna gitmiştir. Bundaki amacı şirketin gelirlerine elkoymak, buradan gelen gelirle Asvan Barajı inşaatını finanse etmek ve kredi isteğini reddeden İngiliz ve Amerikalılardan intikam almaktır. Bu girişimi sonucunda 4 ay kadar sürecek bir uluslararası kriz ortaya çıkmıştır. ${ }^{24}$ Mısır'ın bu kararı alması ve uygulanması sırasında tavizsiz tutumunu sürdürebilmesinin

${ }^{19}$ Ellen Gray, "Blind Loyalty? The Menzies Mission to Cairo During the 1956 Suez Canal Crisis", Diplomacy\&Statecraft, Cilt: 32, Sayı: 4, (2021), s. 86.

"ABD, Ingiltere, Fransa ve IMF'nin kredi vermeme kararı Nasır'ı çok kızdırmıştır. Kararın Nasır'a iletilmesinden bir hafta sonra, 26 Temmuz'da, baraj inşaatı için gereken mali kaynak temini için Mısır’ın Süveyş Kanalı'nın millileştirildiği ilan edilmiştir." Hart, a.g.m., s. 160; Gray, a.g.m., s. 99.

20 "İsrail'in 1948 yılında kuruluşunu ilan etmesinden sonra, 20. yüzyılda Arap dünyasının karşılaştığı en büyük sorunlardan biri de Süveyş Kanalı ve Kanal Şirketi'nin millileştirilmesi olmuştur." Duman, a.g.m., s. 320.

${ }^{21}$ Hahn, a.g.m. , s. 27.

22 Bürkan Serbest, "Süveyş Kanalı'nın Ulusallaştırılması Sorunu ve Süveyş Bunalımı", Manas Sosyal Araştırmalar Dergisi, Cilt: 6, Sayı: 4, (2017), s. 690.

"Nasır'ın altı ilkesi şu şekildedir:

1) Emperyalizmin sona erdirilmesi,

2) Feodalizmin ortadan kaldırılması,

3) Tekellerin ve sermayenin politik egemenliğinin kırılması,

4) Sosyal adaletin sağlanması,

5) Güçlü ulusal ordunun kurulması,

6) Gerçek demokratik bir sistemin kurulması."

Bu konuda daha fazla bilgi için bkz. Leonard Binder, The Ideological Revolution in the Middle East, New York: Wiley\&Sons Inc., 1964, s. 210.

${ }^{23}$ Hahn, a.g.m. , s. 27; Bürkan, a.g.m. , s. 690; Duman, a.g.m. , s. 320.

${ }^{24}$ Hahn, a.g.m. , s. 27.

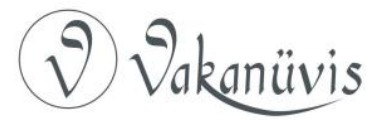


sebepleri arasında tutumunun hukuki olarak sağlam bir zemine dayanması da vardır. Uluslararası Hukuk normlarına ek olarak Birleşmiş Milletler (BM) Genel Kurulu'nun 1952 tarihli "Doğal Kaynakların ve Zenginliklerin Serbestçe İ̧̧letilmesi Hakkı" başlıklı kararı da Mısır'ın aldığı kararının arkasında durmasını sağlayan kanuni dayanaklardan biridir. ${ }^{25}$ Kanalın en önemli ortakları ve kullanıcıları olan İngiltere ve Fransa, Mısır'ın bu tek taraflı kararını kabul edilemez olarak nitelendirmiş ${ }^{26}$ ve bölgeye askeri yığınak yapma yoluna gitmiştir. Buna karşılık Nasır iki ülkeyi bölgedeki eski durumu güç kullanarak yeniden tesis etmeye çalışmamaları konusunda uyarmıştır. ${ }^{27}$ ABD de sorunun çatışma olmadan çözülmesinden yana olduğunu duyurmuştur. ${ }^{28}$

Mısır’ın Süveyş Kanalı'nı millileştirme kararını almasından itibaren uyguladığı tavizsiz tutumunu sürdürebilmesinin bir diğer nedeni ise Soğuk Savaş döneminin iki süper gücü olan $A B D$ ve $S S C B$ 'nin konuya ilişkin tutumudur. $A B D$, sömürge geçmişi olan Batılı ülkelerden ayrışmak ve Arap Dünyası'nın husumetini üzerine çekip onları SSCB tarafına itmemek için Süveyş krizini daha başından itibaren gayet açık ve net bir şekilde diplomasi ile çözmek için girişimlerde bulunmuş ve bölgedeki gerginliğe rağmen, bu durumun bir savaş sebebi olmaması gerektiği konusunda tarafları uyarmıştır. ABD'nin bu bunalımı, uluslararası hukuk sorunu olarak görmemesi Mısır'a kendi haklılığını diretmesi konusunda önemli fırsat sağlamıştır. Mısır'ın ısrarcı tutumunun sebeplerinden bir diğeri de 27 Temmuz 1954'te İngiltere ile imzaladığı ve Büyük Britanya'nın Süveyş Kanalı́ndan çekilmesini öngören mutabakat anlaşmasıdır. Yapılan bu anlaşmayla İngiltere'nin Süveyş Kanalı bölgesini terk etmesi karara ve bir takvime bağlanmıştır.

\footnotetext{
25 Bürkan, a.g.m. , s. 690.

${ }^{26}$ Bkz. The Suez Crisis, 1956, Washington: The Office of the Historian, Foreign Relations of the United States, U. S. State Department, 1990 (FRUS), s. 723. Ayrica bkz. Diane B. Kunz, The Economic Diplomacy of the Suez Crisis, Chapel Hill: University of North Carolina Press, 1991, s. 71-72 ve Hugh Thomas, Suez, New York: Harper and Row, 1967, s. 39 45-46.

"Süveyş Krizi karmaşık kökleri ve sebepleri olan ve Ortadoğu'nun siyasi tarihinde önemli değişikliklere sebep olan karmaşık bir olaydır. Krizin kökleri 1940’lı yıllarda Ortadoğu'da ortaya çıkan Arap-issrail anlaşmazlığı ve bölgedeki sömürge karşıtlığı faaliyetlerine dayandırılabilir." Bkz. Hahn, a.g.m. , s. 26.

${ }^{27}$ Hahn, a.g.m. , s. 27.

${ }^{28}$ Hart, a.g.m., s. 161, Gray, a.g.m. , s. 100.
}

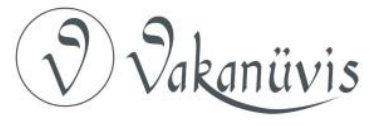


Buna karşın İngiltere, Mısır veya Arap Birliği devletlerine üçüncü bir ülke, bu ülke o dönemde tartışmasız bir şekilde SSCB oluyordu, tarafından yapılacak saldırı durumunda kanal bölgesine müdahale etme hakkını saklı tutmuştur. Anlaşma görüşmelerinin son aşamasında Türkiye de antlaşmanın bir hükmüne dâhil edilmiştir. Bu hükme göre sadece Arap ülkelerine değil, Türkiye'ye de bir saldırı olması halinde Ingiltere, Süveyş Kanalı'na geri dönebilecektir. ${ }^{29}$ Süveyş Kanalı'nın devri hususundaki Mısır-İngiltere Antlaşması'nın ardından beklenenin aksine Mısır’ın Batı dünyası ile olan ilişkileri düzelmemiştir. Ayrıca Mısır, bu dönemde Türkiye ve İngiltere'nin öncülüğünde Ortadoğu'da Sovyet yayılmasına karşı bir engel olarak kurulan Bağdat Paktı'na karşı da olumsuz bir tutum içine girmiştir. Bağdat Paktı'na karşı Mısır'ın izlediği olumsuz tutum daha sonra Türkiye-Mısır ve Türkiye-Irak ilişkilerinin bozulmasına sebep olmuştur. ${ }^{30}$ Mısır, bunun dışında, Sovyetler Birliği'nin Détente'den dolayı öne sürdüğü Barış İçinde Bir Arada Yaşama Politikası'ndan azami şekilde yararlanmaya çalışmıştır. Bu politikasını hayata geçirmesinde SSCB'nin Mısır'a verdiği destek ise daha sonra SSCB'nin Ortadoğu'ya girişini kolaylaştırmıştır. ${ }^{31}$

Nasır'ın kendilerine karşı pervasız ve meydan okuyan bu tavrı yüzünden İngiltere ve Fransa Nasır'ı devirmeye karar vermiştir. ${ }^{32} \mathrm{O}$ dönemde Süveyş Kanalı 75 yıldan fazla bir süredir İngiltere ve Fransa kontrolündeki bir şirket tarafından yönetilmektedir. 1956 Temmuz'unda Mısır Devlet Başkanı Cemal Abdünnasır Süveyş Kanalı’nı millileştirince bölgedeki tüm dengeler altüst olmuştur. 1955'te Kuzey ülkeleri bandıralı tankerler Avrupa kıtası ve İngiltere'ye 66,9 milyon ton

29 "Taraflar arasında 27 Temmuz 1954 tarihinde imzalanan anlaşma, hukuken 'The Heads of Agreement' niteliğinde idi. Ön metinde daha sonra imzalanacak asıl antlaşmanın temel konuları özetlenmişti. Antlaşma genel olarak hukuki bağlayıcılığı olmayan bir mutabakat belgesi idi. Ancak bununla birlikte antlaşma yönündeki ilk adımdı. Tarafların temsilcilerin parafe ettiği bu belgeye atıfta bulunan asıl antlaşma ise 19 Ekim 1954 tarihinde "Süveyş Kanalı Üssüne İlişkin Büyük Britanya ve Kuzey İrlanda Birleşik Krallığı ve Mısır Hükümeti Arasındaki Antlaşma" adıyla Kahire'de imzalandı. İki ülke arasındaki kararlı dostluk ve karşılıklı anlayış temelinde bir ilişkinin gerçekleşmesi arzusuyla yapıldığını ifade eden bir giriş kısmı olan antlaşma 13 madde ve eklerinden oluşmaktaydı." Bürkan, a.g.m. , s. 693.

30 Bürkan, a.g.m. , s. 693.

31 Bürkan, a.g.m. , s. 690.

32 Hahn, a.g.m. , s. 27.

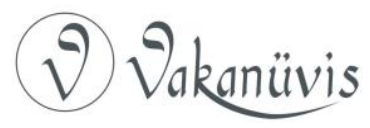


petrol ve petrol ürünleri taşımıştır ve bu taşınan petrolün 20,5 milyon tonu Süveyş Kanalı'ndan geçerek İngiltere'ye gitmiş̧ir. İngiltere'de petrol tüketimi arttıkça İngiliz ekonomisinin Süveyş Kanalı'na olan bağımlılığı da artmıştır. Bahsi geçen yıllarda İngiltere'nin dünyanın geri kalan kısmı ile yaptığı ticaretin \%25'i Süveyş Kanalı'ndan geçerek hedeflerine ulaşmaktadır. ${ }^{33}$ Keza Süveyş Kanalı askeri ve stratejik açıdan da önemlidir çünkü Basra Körfezi'ndeki petrol sahalarına giden en önemli ve kestirme yoldur. ${ }^{34}$ Bu yolun kesilmesi Batı Dünyası'nın enerji kaynaklarına erişimini sekteye uğratacak ve ekonomik açıdan büyük zarara yol açacaktır.

Öncelikle İngiltere, tali olarak da Fransa, Ortadoğu'daki petrol sahalarına erişim için Süveyş Kanalı'na ihtiyaç duymuştur. Bu yüzden Nasır'ın tek taraflı tasarrufu ile ortaya çıkan fiili durum İngiliz Başbakanı Anthony Eden ve Fransız meslektaşı Guy Mollet'ye göre kabul edilemezdir. Her ikisi de Nasır'dan hiç haz etmemekte idi ve ondan kurtulmak istemişlerdir. İngilizlere göre Nasır ve onun faaliyetleri Ortadoğu'daki İngiliz etkisine karşı doğrudan bir tehdittir. Fransızlara göreyse Nasır Cezayir'deki tüm kargaşanın en önemli sebeplerinden ve destekçilerinden biridir. ${ }^{35}$ Çünkü Fransa 1954 yılında başlayan Cezayir'deki bağımsızlık savaşının Kahire'de başlatıldığına inanmıştır. ${ }^{36}$ Bu yüzden İngiltere ve Fransa Nasır'ın Akdeniz'de kendi emperyal çıkarlarını tehdit etmeye çalışmasının önüne geçmeyi istemektedir. İngiltere'nin yönetici eliti Nasır'ın İngiltere'yi Mısır'dan çıkarmaya ve prestijini kırmaya çalıştığını ve Ürdün, Irak ve Suriye'de

\footnotetext{
${ }^{33}$ Kennett Love, Suez, The Twice Fought War, New York: McGraw-Hill Book Company, 1968, s. 366.

“Süveyş Krizi'nden önce, Avrupa petrol gereksiniminin \%75'ini Ortadoğu'dan karşılamaktaydı ve bu petrolün \% 50'si de Süveyş Kanalı'ndan geçerek Avrupa limanlarına ulaşmaktaydı. İngiltere ise petrol gereksiniminin \% 85'ini Süveyş Kanalı yolu ile sağlamaktaydı... Süveyş Kanalı’nın Mısır tarafından devletleştirilmesi üzerine ortaya çıkan kriz esnasında Batılı ülkeler bunalımı aşmak için Batı yarımkürenin petrolüne yönelmişlerdi. Bu da o dönemde petrol fiyatlarının yükselmesine neden olmuştu." Seyfi Taşhan, "Petrol ihtiyaçlar, Buhranlar ve Politikalar", Dış PolitikaForeign Policy, Cilt: 3, Sayı: 2, (1973), s. 14.

${ }^{34}$ Duman, a.g.m., s. 322.

${ }^{35}$ Rathburn, a.g.m.

36 Peter Mansfield, Osmanlı Sonrası Türkiye ve Arap Dünyası, çev. Nuran Ülken, İstanbul: Sander Yayınları, 1975, s. 149. Ayrıca bkz. Grogin, a.g.e. , s. 192.
}

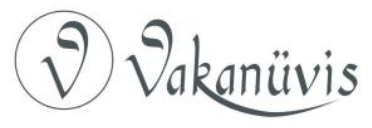


kendi anlayışına yakın grup ve oluşumları başa getirmek için çalıştığını bilmekte ve bundan rahatsız olmaktadır. ${ }^{37}$ Fransızları rahatsız eden en önemli sebep ise, yukarıda ifade edildiği üzere, Nasır'ın Cezayirli direnişçilere destek vermesidir. ${ }^{38}$ Cezayir'de durum giderek daha da nazikleşmeye başladıkça öfkesini bir yere yansıtmak isteyen Fransa tüm olanlardan Nasır'ı sorumlu tutmaya başlamıştır. ${ }^{39}$ Nasır'ı iktidardan düşürmek ve Kanal'ı geri almak için Süveyş Kanalı'nın millileştirilmesinden birkaç gün sonra İngiltere-Fransa ikilisi, Mısır'a karşı askeri güç kullanmaya karar vermiştir. ${ }^{40}$ i ki ülkenin askeri stratejistleri de ivedilikle bir hareket planı üzerinde çalışmaya başlamıştır. Fakat operasyonun planlama aşamasında oyuna yeni bir oyuncu daha dâhil olmuştur; İsrail. İsrail Mısır'ın Sovyetlerden aldığı yeni silahlara intibak etmeden ve kendine karşı kullanmadan önce yok etmek için saldırmayı isteğini uygun olan her platformda ifade etmektedir. ${ }^{41}$

Askeri harekâtın hazırlık aşamasında harekâttan beklenen fayda ve sonuçlar açık bir şekilde tarif edilmiştir. Ancak harekâtla elde edilmesi beklenen siyasi amaçlar için aynı şeyi söylemek mümkün değildir. Ulaşılması beklenen siyasi amaçlar açıklıkla tarif edilmemiş ve ortaya konulmamıştır. Bu nokta harekât planının her zaman en zayıf noktasını oluşturmuştur. İngiltere, Fransa ikilisinin Süveyş Kanalı'na müdahale ve işgal hareketinden beklentisi Mısır'da olası bir rejim değişikliği midir yoksa sadece Süveyş Kanalı bölgesinin geri alınması mıdır, açık değildir. R. W. Rathburn'a göre İngilizlerin harekâtla ulaşmak istediği amaçlar şunlardır:

\footnotetext{
${ }^{37}$ Hahn, a.g.m. , s. 27.

"Yine bu dönemde İngiliz İmparatorluğu'nun çoğu dağılmıştı ve geri kalan kısmı da bağımsızlık taleplerini sürekli gündeme getiriyordu." Bkz. Rathburn, a.g.m.

38 "Fransa'nın sorunu ise Cezayir İsyanı idi ve Nasır'ın bunu desteklediğine inanıyorlardı."Bkz. Rathburn, a.g.m. Ayrıca bkz. Hahn, a.g.m. , s. 27; William M. Wright, Michael C. Shupe, Niall M. Fraser ve Keith W. Hipel, "A Conflict Analysis of the Suez Canal Invasion of 1956", Conflict Management and Peace Science, Cilt: 5, Sayı: 1, 1980, s. 28.

${ }^{39}$ Thomas, a.g.e. , s. 152

40 “Süveyş Kanalı'nın Mısır tarafından devletleştirilmesinden yalnızca bir gün sonra, Büyük Britanya hükümeti askeri bir operasyon yapılması konusunda gizli bir planın hazırlıklarına başladı." Grogin, a.g.e. , s. 193.

${ }^{41}$ Rathburn, a.g.m.
}

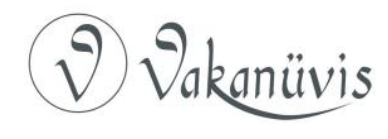


1. Nasır'ın devrilmesi,

2. Savaşan tarafların birbirinden ayrılması,

3. Süveyş Kanalının bu bahane ile işgali,

Fransızların harekâtla ulaşmak istediği amaçlar şunlardır:

1. Petrol kaynakları ve ithal rotasının güvenceye alınması,

2. İsrail'in güvenliğinin sağlanması,

3. Cezayir İsyanı'na olan dış desteğin kesilmesi. ${ }^{42}$

İngiltere'nin II. Dünya Savaşı sonrası dönemde savunma politikası iki tür savaşı öngörmüştür:

a. NATO çerçevesinde SSCB ile topyekûn savaş,

b. Sömürgelerinde ortaya çıkan küçük çaplı ayaklanmalar. ${ }^{43}$

1956 yılı yazında İngiliz kara ordusunun büyük kısmı Sovyet tehdidi yüzünden Almanya'da bulunmaktadır. Kraliyet Deniz Piyadeleri ve Paraşütçüleri (Ingiltere'nin ana acil müdahale gücü) Kıbrıs'taki karışıklıklarla uğraşmaktadır. Ek olarak Ingiliz paraşütçülerin amfibi hareket ve paraşüt atlama eğitimleri eksiktir. Silahlı kuvvetlerin geri kalan kısmı olan kara birlikleri ile İngiliz Hava Kuvvetleri de Malaya'daki olağanüstü hali sürdürmek için çalışmaktadır. Fransızlar ise Vietnam'daki hezimetten sonra Cezayir'deki bağımsızlık savaşıyla meşguldür. Tüm bu olumsuzluklara rağmen Fransız-Ingiliz strateji uzmanları yeteri kadar hava ve deniz gücüne sahiptiler. Saldırı planı çerçevesinde askeri birlikler harekât için yeniden konuşlandırılmış ve eğitilmiştir. Yine bu kapsamda yedek askerler göreve çağrılmıştır. ${ }^{44}$

İngiltere, böyle bir harekâtta ABD'nin en azından tarafsız kalacağını çünkü ABD’nin 1956 yılı Başkanlık seçimlerine odaklandığını düşünmüştür. Bu dönemde ABD-İngiltere ikili ilişkileri İngiliz Başbakanı

\footnotetext{
${ }^{42}$ Rathburn, a.g.m.

${ }^{43}$ Anthony Nutting, No Ends of a Lesson, The Story of Suez, New York: Clarkson N. Potter, 1967, s. 55.

${ }^{44}$ Robert Murphy, Diplomat Among Warriors, New York: Doubleday, 1964, s. 378; Keith Kyle, Suez, New York: St. Martin's, 1991, s. 167-169; Eric Groove, Vanguard to Trident: British Naval Policy Since World War II, Londra: Bodley Head, 1987, s. 186.
}

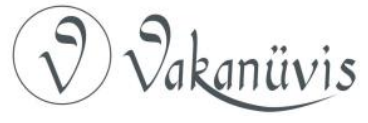


Anthony Eden ve ABD Dışişleri Bakanı John Foster Dulles arasındaki düşmanlık ve husumet yüzünden bozuktur. ${ }^{45}$

Mısır'ın Süveyş Kanalı'nı millileştirme kararından birkaç hafta sonra Ingiliz, Fransız ve $A B D$ hükümet temsilcileri arasında üst düzey görüşmeler yapılmıştır. ABD Başkanı Eisenhower, taraflar arasındaki gerginliği azaltması ve tansiyonu düşürmesi için Dışişleri Bakanı John Foster Dulles'ı Londra'ya göndermiştir. ${ }^{46}$ Eisenhower, Süveyş Krizi'ne üç temel ve birbirine bağlantılı noktadan bakmaktadır. Öncelikle Fransa ve İngiltere'nin birden bire ellerinden alınan Kanal Şirketi'ni geri alma isteğini makul görmektedir ama bunun yanında Mısır'ın gerekli bedeli ödeyerek şirketi alma hakkının olduğunu da kabul etmektedir. Eisenhower, ayrıca krizin çatışmaya dönmesinin önlenmesi ve sorunun görüşmelerle çözülmesine taraftardır. Böyle yaparak Sovyetlerin bu sorunu suiistimal etmesini ve sürece katılmasını önlemeyi istemiştir. $\mathrm{Bu}$ amaçla krizi idare etmesi ve yönetmesi için Dışişleri Bakanı John Foster Dulles'ı görevlendirmiştir. Ama ABD'nin tüm çaba ve girişimleri sonuçsuz kalmış ve İngiltere-Fransa ikilisinin savaş hazırlıkları devam etmiştir. İkinci olarak Eisenhower, krizi sona erdirmek için Arap devlet adamlarını da sürece dâhil etmeye çalışmıştır. Bu yüzden İngiliz-Fransız ortak askeri harekâtına, hele buna bir de İsrail'in katılmasına, kesinlikle karşı çıkmıştır. ${ }^{47}$ Çünkü İsrail'in krize katılımı onu tamamen içinden çıkılmaz bir hale getirecek ve bölgedeki Batı karşıtlı̆̆ı ve Sovyet etkisini arttıracaktır. Ayrıca krizin büyümesi halinde Arap dünyasında oldukça popüler olan Nasır'ın kahraman haline geleceği ve popülaritesinin çok daha fazla artacağı da bilinmektedir. ${ }^{48}$ Üçüncü olarak ABD, İsrail'i Süveyş krizinden uzak tutmaya çalışmıştır. Çünkü $A B D$, Mısır-Issrail ve Mısır-Fransa-Ingiltere çatışmalarının tüm Ortadoğu'yu içine alacak bir istikrarsızlığa sebep olmasından çekinmiştir. ${ }^{49} \mathrm{Bu}$ yüzden Birleşmiş

\footnotetext{
${ }^{45}$ Rathburn, a.g.m.

${ }^{46}$ Rathburn, a.g.m.

47 “iddialara göre Eisenhower'ın Fransa, İngiltere ve İsrail'e baskı yapmasının ardında yatan sebeplerden biri de Arap ülkelerinin, ama özellikle de Mısır'ın sempatisini kazanmaktır." Hart, a.g.m., s. 158.

48 Benzer görüş için bkz. Bürkan, a.g.m. , s. 701.

${ }^{49}$ Hahn, a.g.m. , s. 27.

"ABD, gerek Başkanlık seçimlerinin arifesinde olmasından gerekse de Sovyetler Birliği'nin de çatışmanın içine girme olasılığından çekinmesi nedeniyle böyle bir harekâtın yapılmasını kesinlikle istemiyordu."
}

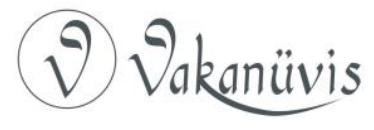


Milletler (BM) devreye sokulmuştur. Diplomatik süreç yavaş ilerlese de Ekim ayında Mısır ve BM delegasyonları görüşmelerde belli bir ilerleme elde etmiştir. Görünürde İngiliz-Fransız oldu bittisine zemin hazırlayacak olan ana sebep (casus belli) ortadan kalkmıştır. Planın en önemli parçalarından birisi olan İsrail yine bu dönemlerde artan Fedain saldırıları yüzünden sıkıntılı bir dönem geçirmektedir. ${ }^{50}$ Ancak yine de Ingiltere-Fransa-İsrail üçlüsü müdahale planı üzerinde çalışmaya devam etmiştir.

22 Ekim'de Paris'in banliyölerinin birinde gizlice bir araya gelen İsrailli, İngiliz ve Fransız yetkililer düzenlenen toplantıda ay sonunda İsrail'in Sina'ya girmesi ve Kanal bölgesini işgal etmesi konusunda anlaşmıştır. İngiltere, Ortadoğu'daki iktisadi çıkarlarını korumak için Fransa ve İsrail'in Mısır'a saldırmayı öngören komplosuna destek vermeye devam etmiştir. ${ }^{51}$ Plan gereğince İsrail, Fedain saldırıları ve

Sermet Gökdeniz, "1956 Süveyş Kanalı Buhranı ve Port Sait Harekâtı”, Donanma Dergisi, Cilt: 71, Sayı: 426, (1959), s. 10.

${ }^{50}$ Bkz. Nutting, a.g.e. , s. 77-78; Thomas, a.g.e. , s. 64,83 ve 86-87; Groove, a.g.e. , s. 187.

${ }^{51}$ Rathburn, a.g.m.

“Ekim ayında kriz ABD’nin hiç beklemediği bir istikamete gitmeye başladı. Amerikalılardan habersiz şekilde İngilizler ve Fransızlar İsrail'le Mısır'a koordineli bir saldırı yapılması konusunda görüşüp, anlaşmaya varmışlardı. Anlaşma sonrasında yapılan plana göre İsrail Sina Yarımadası'nı işgal edecek, İngiltere ve Fransa ikilisi de yaşanan çatışmanın kendi iktisadi çıkarlarını tehdit ettiği bahanesi ile taraflara çatışmayı hemen sonlandırmalarını ve Süveyş Kanalı'ndan güvenli geçiş sağlanabilmesinin temini bu bölgeden çekilmelerini öngören bir nota vereceklerdi. Mısır'ın saldırıya uğramanın ve Avrupa ile ilgili hissiyatı sebebiyle kabul etmeyeceğini bildikleri için, bu isteği reddinden 48 saat sonra da Avrupalılar Mısır havaalanlarını bombalayacaktı. Daha sonra Kanal'ı işgal edecek ve Nasır'ı devireceklerdi." Bkz. Hahn, a.g.m. , s. 28.

"23 Ekim 1956'da Fransa, Sevres'te taraflar arasında gizli bir toplantı yapıldı. Bu toplantıya Başbakanlar, Dışişleri ve Savunma Bakanları katıldı. 3 gün süren toplantıda bir karara varıldı. Bu karara göre; ilk olarak İsrail Sina'da Mısır birliklerine saldıracak; Mitla Geçidi yakınlarına İsrailli paraşütçüler indirilecekti. Bu hareket ve ona karşı Mısır'ın gösterdiği direniş İngiltere ve Fransa tarafından Kanal'ın güvenliğine tehdit olarak ilan edilecekti. Bundan sonra İsrail'den saldırısını durdurması ve Kanal bölgesinden 10 mil kadar geriye çekilmesi istenecekti. Aynı istekler eşzamanlı olarak Mısır'dan da istenecekti ama Mısır'dan ek olarak Süveyş, Port Said ve İsmailiye'den de çıkması istenecekti. Sina'daki toprakları işgal edilmiş olan Mısır'ın bu isteğe karşı çıkacağı ise açıktı. Taraflara isteklerinin yerine getirilmesi için 12 saat verecek olan Avrupalı güçler bu süre sonunda ise ikazda bulunmadan saldıracaklardı. Ingiltere

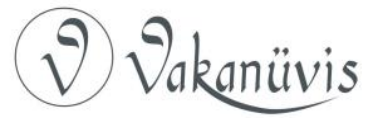


Mısır'ın bu saldırılara desteği ve kendisine karşı hasmane tutumunu öne sürerek Sina yarımadasında Mısır'a saldıracaktır. Saldırı ve İsrail ilerlemesinden sonra İngiltere ve Fransa devreye girecek, bu önemli ticaret yolunda vuku bulan çatışmanın hayati çıkarlarını tehdit ettiği ve maddi kayba uğradıklarını iddia ederek çatışmanın bir an önce sonlandırılmasını talep edeceklerdir. Ek olarak çatışan tarafların ateşkes ilan edilip, birbirlerinden ayrılmaları ve güvenli bir mesafeye çekilmeleri, bu sayede Süveyş Kanalı'nda tekrar sulhun tesisini isteyeceklerdi. Çatışan tarafların birbirinden ayrılması için istenecek çözüm her iki gücün de Süveyş Kanalı kıyısından 10 mil kadar geri çekilmesi olarak planlamıştır. Eğer Mısır bu teklifi kabul etmezse, kabul etmeyeceği de açıktı, İngiliz-Fransız ortak askeri harekâtı başlayacaktır. Fakat harekât saldırgan tarafı değil de savunmadaki Mısır'ı hedef alacaktır. Müttefik saldırısında öncelik hava indirme ve çıkartma harekâtlarını zora sokabilecek olan Mısır Hava Kuvvetlerinin yok edilmesi olacaktı. İngiltere kendi kurduğu ve eğittiği Mısır Hava Kuvvetlerini ve içyapısını iyi bildiği için bunu yapabilecek güce ve bilgiye sahipti. Ama bunu çabuk yapmak zorunda idi yoksa zorda kalacak olanlar sadece İngiliz-Fransız ortak gücü askerleri değil Sina Çölü'nde ilerleyen İsrail askerleri de olacaktı. ${ }^{52}$

Harekâttan önce, Ekim ayı içerisinde, İngiltere-Amerika arasındaki istihbarat akışı tek taraflı olarak oldukça azalmıştır. Bu anormal bir durumdu ve özellikle Amerikalıların dikkatini çekmesi imkânsızdır. Öyle de olmuş, ABD İngiltere'nin bir şeylere hazırlandığını fark etmiştir. Buna ek olarak Fransa-Ingiltere arasında aynı dönemde artan istihbarat ve enformasyon trafiği de Amerikalıların dikkatini çekmiştir. Yine bu dönemde İsrail'in de büyük ölçekli bir seferberlik ilan ettiği haberi gelmiştir. Ama tüm bu olanlar Washington'da dar bir çerçevede takip edilmiş ve dışarıya sızdırılmamaya çalışılmıştır. Bu gelişmelerin öncesinde 27 Eylül'de Doğu Akdeniz'de uçan U-2 Casus uçaklarının çektiği hava fotoğrafları sonucunda İsrail'de Fransız Hava Kuvvetleri'ne ait uçakların olduğu da ortaya çıkmıştır. Yine uçaklar ve uydulardan alınan yüksek çözünürlükte hava fotoğrafları Fransız ve İngiliz savaş

Başbakanı Eden bu planı kabul etmişti ama bir şartı vardı; plan asla kamuoyuna sızdırılmayacaktı." Daha fazla bilgi için bkz. Love, a.g.e. , s. 463-466.

52 The Suez Crisis, 1956, ... (FRUS), s. 776. , Ayrıca bkz. Keith Kyle, Suez: The Twice Fought War, New York: McGraw-Hill, 1969, s. 461-463.

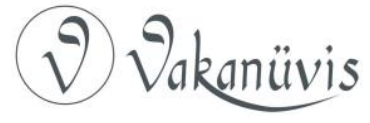


gemilerinin Toulon, Malta ve Kıbrıs'taki limanlarda cephane ve malzeme ikmali yaptığını da göstermiştir. Tüm bunların savaş hazırlığı olduğu açıktır. ${ }^{53}$

Fransız ve İngiliz ortak donanmasındaki gemilerinin toplamı 100 'den fazladır. Plan gereği İngiliz-Fransız ortak donanması kara birliklerini Süveyş Kanalı kıyısına taşıyacak ve kıyı savunmasını çıkartmadan önce deniz topçusu ile yumuşatacaktı. Ardından da çekirdeğini İngiliz deniz komandoları ile paraşütçülerinin oluşturduğu saldırı gücü karaya çıkacaktır. Bu dönemde İngilizlerin Akdeniz'de iyi bir askeri üsler ağı vardır ama Libya ve Ürdün'de antlaşmalar çerçevesinde kurulmuş olan üslerin kullanılması ihtimali yoktur. Kıbrıs'ın liman ve havaalanlarının kapasitesi ise bu büyüklükte bir kuvveti desteklemeye yeterli değildir. Kıbrıs'tan kalkacak uçakların menzillileri sınırlı olduğu için hedef bölgede havada kalma süreleri oldukça az olmuştur. Malta ise çok uzaktır, bu yüzden de uçak gemileri planın gerçekleştirilmesinde hayati önemde olmuşlardır. ${ }^{54}$ Bu sırada Kraliyet Donanması uçak gemilerinde modernizasyona gitmiştir, ${ }^{55}$ bu yüzden de personelin eğitim eksiği bulunmaktadır.

1956 'da Akdeniz'in güneydoğusunda bu iki donanmaya ek olarak üç diğer donanma grubu daha vardı: Mısır donanması, İsrail donanması ve ABD Altıncı Filosu. Mısır donanması gemilerinin hepsi İkinci Dünya Savaşı'ndan kalmadır ve ingiltere'den tedarik edilmiştir. Ancak 1955 'ten sonra Nasır Sovyetlerden modern gemiler de almıştır. İsrail Donanması Mısır'ınkine göre daha küçüktür. Amerikan Altıncı Filosu ise 50 kadar gemiden oluşmaktadır. Filoda 200 uçak $^{56}$ ve 25.000 kadar asker de bulunmaktadır. İngiliz ve ABD donanmaları arasında normalde

53 "Dönemin CIA Direktörü Richard Bissel de tüm bu hazırlıkların boş yere yapılmadığını ifade etmişti." Michael R. Beschloss, Mayday: Eisenhower, Khruschev and the U-2 Affair, New York: Harper and Row, 1986, s. 137-138; Leonard Mosley, Dulles: A Biography of Eleanor, Allen and John Foster Dulles and Their Family Network, New York: Hodder and Stoughton 1978, s. 442.

54 Bkz. Thomas, a.g.e. , s. 72; Donald Neff, Warriors at Suez, New York: Simon and Schuster, 1981, s. 289. Ayrica bkz. Norman Freidman, British Carrier Aviation: The Evolution of the Ships and Their Aircraft, Annapolis: Naval Institute Press, 1989.

55 Üç yıl önce Kore Savaşı'nda İkinci Dünya Savaşı'nın bakiyesi düz güverteli uçak gemileri ve pervaneli uçaklar kullanan İngiliz Donanması bu dönemde eğimli güvertesi olan uçak gemilerine geçmişti. (M.E.K.)

${ }^{56}$ ABD Donanmasına bağlı uçaklar nükleer silah taşıma kapasitesine de sahipti. (M.E.K.)

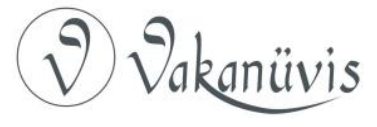


üst düzeyde işbirliği vardır ama bu ilişki Ekim ortalarında sekteye uğramıştır. $O$ dönemde Amerikalılar hiçbir şeyden haberdar olmadıklarını iddia etmişlerdir ama İngiliz-Fransız donanmasının limanlarından hareket etmesinden sonra bölgedeki Amerikan vatandaşları tahliye edilmeye başlanmıştır. Ayrıca Altıncı Filo'nun Komutanı Amiral Charles R. Brown'ı Donanma Kurmay Başkanı Amiral Arleigh Burke durumun oldukça gergin olduğu ve her türlü duruma hazırlıklı olunması gerektiği konusunda uyarmıştır.

O dönemde İngiliz-Fransız-İsrail güçlerine önemli bir tehdit olan Mısır Hava Kuvvetleri 110 kadar Mig-15 süpersonik savaş uçağı, 48 il28 bombardıman uçağı ve bir dizi eski savaş uçağından oluşmaktadır. Mısır Hava Kuvvetleri 7 hava üssüne dağılmıştır. Ama Mig'ler Mısırlılara yeni teslim edildiği için Mısırlı pilotların bu uçaklara intibakı henüz tamamlanmamıştır. Fakat tüm bunlara rağmen Mısırlılar İsraillilerin tahmininden daha fazla direnç göstermiştir. ${ }^{57}$

\section{Süveyş Kanalı’nın İşgali}

Temmuz ayı sonunda İngiliz Genelkurmayı taslak bir saldırı planı hazırlamıştır. Bu planın kod adı "Silahşör (Musketeer)"dür. ${ }^{58}$ Ağustos'ta Harekât Kurmay Başkanlığı İngiliz ve Fransız subaylardan oluşturulmuştur ancak ana komuta İngilizlerde kalmıştır. Planın hazırlanmasına rağmen harekât birkaç defa ertelenmiştir. Fakat tüm gecikmelere rağmen 19 Eylül'de ana saldırı planı kabul edilmiştir. Plana göre çıkartma Port Said'e yapılacaktır ama günü hala tam olarak kararlaştırılmamıştır. Beklemeler yüzünden denizin askeri ekipmana verdiği zarar (korozyon) sebebi yüzünden bazı gecikmeler ortaya çıkmıştır. Tüm bunlara rağmen 27 Ekim'de İngiliz Donanması Malta'dan denize açılmıştır. Ertesi gün de Fransız Donanması Kuzey Afrika'daki üslerinden yola çıkmış ve İngiliz Donanmasına katılmıştır. 29

57 Brian Cull, David Nicolle ve Shlomo Aloni, Wings Over Suez: Air Operations During the Sinai and Suez Wars of 1956, Londra: Grub Street, 1996, s. 123 ve 169. Ayrica bkz. The Suez Crisis, 1956 , ... (FRUS), s. 939.

58 "Silahşör Operasyonu-Operation Musketeer 1956 yılında Fransa ve İngiltere'nin Süveyş Kanalı'nı işgal girişiminin adıdır." Bkz. Rathburn, a.g.m.

"5 Kasım 1956'da İngiltere ve Fransa Süveyş Kanal bölgesini işgale başladılar. "Operation Musketeer" adı verilen bu askeri harekât kara savaşı kısmı 42 saatten kısa sürdü." Bkz. Rathburn, a.g.m.

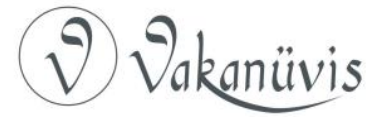


Ekim'de ise İsrailliler Sina yarımadasında saldırıya geçmiştir. Tüm deniz güçleri 30 Ekim'de savaş hattında toplanmaya çalışmıştır ve hareketleri ABD'nin casus uçakları U-2'ler tarafından yakından izlenmiştir. ${ }^{59}$

Taraflar arasındaki ilk temas 29 Ekim günü öğleden sonra saat 17:00 sularında gerçekleşmiştir. ${ }^{60} 395$ kişilik İsrailli paraşütçü birliği Sina Yarımadası içerisinde yer alan Mitla Geçidi'nin doğusuna inmiş ve harekâtı başlatmıştır. ${ }^{61} \mathrm{Bu}$ hareket İngilizler ve Fransızlara Süveyş Kanalı'nın tehdit altında olduğu iddiasını gündeme getirme fırsatı vermiştir. İsrail, paraşütçülerini desteklemek için zırhlı birliklerini de Sina'ya gönderince çatışma daha da büyümüş ve bu iddiayı savunmak daha kolay hale gelmiştir. ${ }^{62}$ İsrail Ordusu hedeflerini hızlı bir şekilde ele geçirmiş İngiliz ve Fransız güçleri hazırlıklarını tamamlayamadan Kanal'ı tehdit etmeye başlamıştır. ${ }^{63} 30$ Ekim'de taraflar arasında daha önce kararlaştırılmış olan ültimatom İsrail ve Mısır'a verilmiştir. Mısır topraklarında ilerlemiş olan İsrail bu ültimatomu hemen ve itirazsız olarak kabul ederken Mısır bunu kabul etmemiş, bunun sonucunda ise Fransa-İngiltere ikilisinin saldırısına uğramıştır. ${ }^{64}$

Londra ve Paris'teki müttefiklerinin saldırısından ve sorumsuz tavrından dolayı oldukça kızan ABD Başkanı Eisenhower bu girişimin Arap ülkelerini Sovyetlerin yanına itebileceğinden korkmuştur. Bu yüzden savaşı durdurmaya çalışmış, bu amaçla çatışan taraflara yaptırım uygulanmasını teklif etmiştir. ABD, BM Genel Kurulu'ndan bir ateşkes kararı çıkartmış ve çatışan tarafları ayırmak için alelacele bir BM Gücü (United Nations Emergency Force-UNEF) kurulmuştur. Ama UNEF birlikleri bölgeye konuşlanmadan önce İngilizler ve Fransız paraşütçüler 5 Kasım'da Kanal bölgesine inmiştir. Bu hareket, krizi daha da derinleştirmiş ve daha tehlikeli bir hale getirmiştir.

\footnotetext{
59 Beschloss, a.g.e. , s. 137.

60 "Savaş 29 Ekim'de İsrail'in Sina yarımadasındaki Mısır güçlerine saldırısı ile başladı." Bkz. Hahn, a.g.m. , s. 28.

"Israil, Ekim ayı sonlarında Mısır’a saldırdı." Bkz. Rathburn, . a.g.m.

${ }^{61}$ Michael H. Coles, "Suez, 1956-A Successful Naval Operation Compromised by Inept Political Leadership", Naval War College Review, Cilt: 59, Sayı: 4, (2006), s. 108.

62 Moshe Dayan, Diary of Sinai Campaign, New York: Schocken Books, 1967, s. 79.

${ }^{63}$ Rathburn, a.g.m.

64 Thomas, a.g.e. , s. 130. Ayrıca bkz. André Beaufre, The Suez Expedition 1956, Londra: Faber and Faber 1969, s. 82.
}

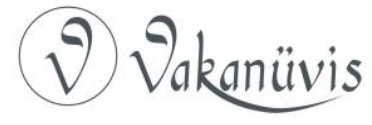


Macaristan'daki müdahalesinden dikkatleri başka yöne çekmek isteyen SSCB, ABD ve Avrupa'yı Süveyş'teki çatışmaya müdahil olmakla, Ingiltere-Fransa ikisinin de başkentleri olan Londra ve Paris'i nükleer silahlarla vurmakla tehdit etmiştir. ABD istihbarat raporları da SSCB güçlerinin çatışmaya müdahale için Suriye'de toplanmaya başladığını belgelemiştir. ${ }^{65}$

31 Ekim gecesi İngiliz-Fransız ortak donanması ile Mısır donanmasına bağlı gemiler karşı karşıya gelmiştir. Bu karşılaşma sonrasında vuku bulan çatışmada Mısır donanmasına ait olan Dimyat destroyeri batmış; gemi mürettebatından sadece 69 kişi kurtulabilmiştir. Yine aynı akşam Mısır firkateyni İbrahim el Evvel İsrail kıyısına 5 mil kalana kadar yaklaşmış ve kıyıya ateş açmıştır. (İsrailliler onu Amerikan gemisi sanmıştır.) Bu sırada Hayfa limanında ikmal yapan Fransız gemileri Mısır gemisine karşılık vermiş ve onu kıyıdan uzaklaşmak zorunda bırakmıştır. Takip eden İsrail gemi ve uçaklarının ateşi üzerine Mısır gemisi teslim olmak zorunda kalmıştır. Ele geçirilen gemi limana çekilip, tamir edilmiş "Hayfa" ismi ile yeniden denize açılmıştır.

Çıkarma gücünün ise 6 Kasım'da Mısır açıklarına varacağı tahmin ediliyordu. Bu süre zarfında Müttefikler, Mısır askeri hedeflerine hava saldırıları düzenleyerek Mısırıları meşgul etmeyi ve hedefleri çıkarma öncesinde yumuşatmayı planlamıştır. Bu kapsamda düşünülen hava saldırısının ilk safhası 31 Ekim'de başlamış ve Mısır Hava Kuvvetleri'nin baskılanması amaçlanmıştır. Saldırıya Kıbrıs'tan kalkan İngiliz bombardıman uçakları da katılmış ve Mısır havaalanlarını hedef almışlardır. Fakat saldırının yükünü donanma uçakları çekmiştir. Çünkü Kıbrıs'tan kalkan uçaklar, daha önce de ifade edildiği üzere fazla cephane taşıyamamış ve bu halde iken bile hedef üstünde en fazla 15 dakika kalabilmiştir. Mısır da bombardıman filosunu yok olmaktan kurtarmak için güneydeki havaalanlarına çekmiştir. ${ }^{66}$ Tüm bu saldırılardan sonra, 2 Kasım itibarıyla Mısır Hava Kuvvetleri'nin büyük kısmı nötralize edilmiştir.

\footnotetext{
65 Hahn, a.g.m. , s. 28.

${ }^{66}$ Kyle, Suez, s. 409-410.
} 
Kraliçe'nin kuzeni, Hindistan'ın son Kral Naibi ve o tarihlerde İngiliz donanmasının komutanı olan Louis Mountbatten harekâtın etik ve strateji açısından yanlış ve sakıncalı olduğunu dönemin Başbakanı olan Anthony Eden'e ifade etme ihtiyacı duymuştur. Ona göre harekât aslında İngiltere'yi tam bir açmaza sokacaktır. Eğer harekât başarılı olursa yeni kurmaya çalıştığı düzen içinde Süveyş'in doğusundaki tüm kolonilerinde askeri kontrolü terk etmeyi planlayan İngiltere, Süveyş'i işgal etmek zorunda kalacaktır. Bu da Ortadoğu ve dünya genelinde tasfiye etmeye çalıştığı askeri ve ekonomik yükümlülüklerini sil baştan geri üzerine almasına sebep olacaktır. Bunun dünya genelinde doğuracağı tepki de cabasıdır. Kaybederse de İngiltere dünya genelinde çok ciddi bir prestij kaybına uğrayacaktır. Yenilginin yol açacağı moral, siyasi ve iktisadi bedel ise çok ağır olacaktır. Bu yüzden Mountbatten, gerek siyasi gerekse de askeri kanat içinde yer alan muhaliflerin sesini duyurmak ve harekâtın sorumluluğunu paylaşmamak için istifa etmek istemiştir ama bu isteği Eden tarafından kabul edilmemiştir. Bunun üzerine son bir kez şansını denemek isteyen Mountbatten, Eden'i telefonla aramış ve saldırıyı durdurmasını istemiştir ama bu isteği kabul görmemiştir. ${ }^{67}$

3-5 Kasım tarihleri arasında cereyan eden hava saldırılarının ikinci safhasında ise Mısır'ın havaalanları dışındaki askeri tesisler hedef alınmıştır. Özellikle Port Said'e ulaşan kara ve demiryolu öncelikli hedef olmuştur. Buradaki temel hedef ise Cemil Köprüsü'dür. Bu köprü Port Said'i Mısır'ın geri kalan kısmına bağladığı için hayati önemdedir. Ama istihbarat eksiği olan İngilizler bu köprüyü ancak 27 sortide tahrip edebilmiştir. Mısırlılar da Süveyş Kanalı'na İngiliz ve Fransız gemilerinin girmesini engellemek için 50'ye yakın gemiyi kanalda batırmış ve kanalı bloke etmiştir. Bu sırada Suriye Ordusu da Irak Petrol Şirketi'nin petrol pompalarını tahrip etmiştir.

Artan çatışmalar yüzünden Amerikan Altıncı Filosu'na bölgedeki Amerikan vatandaşlarını tahliye etme emri verilmiştir. ABD uçak gemisi Coral Sea, 4 Kasım'da Ingiliz savaş grubunun ortasından geçmiştir. Ingiliz Filo Komutanı Amerikalılardan bölgeyi terk etmelerini istemiştir. $A B D$ gemisi bu isteği kabul etmemiştir ama ne yapacağını da üslerine

67 William Godfrey Fothergill Jackson ve Dwin Bramall, The Chiefs: The Story of the United Kingdom Chiefs of Staff, Londra: Brasseys's, 1992, s. 298.

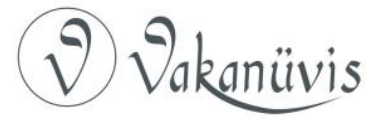


danışmıştır. Bölgede kalması emrini alınca da aynı minval üzere devam etmiştir. Bu da dost ateşi ile vurulma ihtimalini, her iki taraf için de arttırmıştır. Krizin daha fazla büyümesini istemeyen $A B D$ savaş gemilerini hemen her fırsatta çatışan tarafların arasına sokmuştur. $\mathrm{Bu}$ sayede Amerika İngiliz-Fransız saldırısını durdurmaya veya en azından yavaşlatmaya çalışmıştır. Çünkü çatışmanın derinleşmesi halinde Mısır'ın SSCB'ye iyice yakınlaşması veya Sovyetlerin bu çatışmayı kullanma ihtimalleri vardır. Her iki durumda da Ortadoğu'da Sovyet etkisinin artacağı açıktır ve ABD bunu hiç istememektedir.

Mısır'a İsrail, İngiltere ve Fransa ortak saldırısı dünya genelinde büyük bir tepkiye sebep olmuştur. Öyle ki, Avustralya ve Yeni Zelanda hariç, İngiliz Uluslar Topluluğuna dâhil devletler dahi saldırıyı kınamıştır. Dış dünyadan gelen tepkiler nedeniyle İngiliz kamuoyu da bölünmüştür. Avam Kamarası'nda yaşanan sert tartışmalar yüzünden 20 yıl aradan sonra ilk kez oturum ertelenmek zorunda kalmıştır. Anthony Eden harekât hakkında muhalefeti tam olarak bilgilendirmemiştir ve Parlamento'da yaşanan tartışmalarla bunun diyetini ödemiştir. İngilizlerden farklı olarak Fransa ve İsrail de ise ülke içinde harekâtla ilgili hiç muhalefet yoktur.

ABD Başkan Eisenhower, İngiltere, Fransa ve İsrail üçlüsünün düşünmeden yaptığı bu hareketin SSCB'nin işine yaracağı için oldukça kızgındır. Eisenhower'in kızgınlığı ABD'nin BM Güvenlik Konseyi'ne sunduğu ateşkes çağrısı İngiltere ve Fransa tarafından veto edilince daha da artmıştır. Bunun üzerine $A B D$, aynı öneriyi iki gün sonra $B M$ Genel Kurulu gündemine taşımış ve öneri Genel Kurul'da oy çokluğu ile kabul edilmiştir. ${ }^{68}$ Sovyetler Birliği ise ayağına gelen bu fırsatı kaçırmamış ve işgali Ortadoğu'da zemin kazanmak ve ilgiyi Macaristan'ı işgallerinden başka tarafa çekmek için uygun bir fırsat olarak değerlendirmiş ve başarıyla kullanmıştır. İngiltere cephesinde Eden gerek içeriden gerekse dışarıdan gelen yoğun baskı üzerine geri adım atmak zorunda kalmıştır. ${ }^{69}$

68 "Kabul edilen bu öneride Kanal bölgesine B.M. Barış Gücü gönderilmesi de öngörülüyordu." Bkz. The Suez Crisis, 1956, ... (FRUS), s. 867-873. ve Neff, a.g.e. , s. 377-397. Ayrıca bkz. Anthony Gorst ve Lewis Johnman, The Suez Crisis, New York: Routledge, 1997, s. 106 ve 115.

${ }^{69}$ Bkz. Nutting, a.g.e. , s. 165; Neff, a.g.e. , s. 400; Groove, a.g.e. , s. 193.

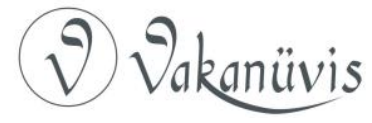


Tüm bu gelişmeler yaşanırken, denize açılan saldırı gücünün 6 Kasım'da Port Said'te olması planlanmıştır. Ancak diplomatik açıdan sıkışan Fransızlar ve İsraillilerin çıkartmanın bir an önce başlamasını istemiştir. Fransızlar, Kanal bölgesine hava indirmesi yapılması için Eden'i sıkıştırmıştır. Bunun üzerine Eden tepkilere kulaklarını tekrar tıkamış ve hava indirme harekâtına onay vermiştir. Bu sayede tüm harekâtın dört gün içerisinde sona ereceği planlanmıştır. ${ }^{70}$ Plan gereğince 5 Kasım sabahı 1.100 kişilik karma paraşütçü birliğ ${ }^{71}$ Port Said'in $7 \mathrm{~km}$. batısına inmiştir. Saat 04:00'da kısa bir süre sonra Silahşör/Musketeer Operasyonu'nun ikinci safhası başlamıştır. Planın bu safhası Port Said'e ve Port Fuad'a paraşütçü indirmesini öngörmektedir. ( $\mathrm{Bu}$ operasyonun adı Operation Omelette idi.) ${ }^{72}$ Operasyon bir kere başladığında her şey plana uygun gitmiştir. 5 Kasım'da İngiliz ve Fransız paraşütçüleri Port Said yakınlarındaki önemli noktalara inmiş ve hedeflerini hızla ele geçirmiştir. Öğleden sonra takviye kuvvetler de bölgeye indirilmiştir. Ertesi gün ise kara birlikleri kıyıya çıkmaya başlamıştır. Saldırının bu safhasında ilk kez gemiden karaya helikopterle asker taşınmıştır. ABD'deki pek çok kişi bu harekâtı tipik bir sömürgeci devlet refleksi olarak gördüklerini ifade etmiştir. ${ }^{73}$ Ingilizlerin ilerleyişi kıyıdaki direniş sebebiyle yavaşlarken sivil kayıplarını umursamayan Fransızlar yollarına devam etmiştir. Bu arada donanma uçakları da hava desteği ile paraşütçülerin yollarını açmaya çalışmıştır çünkü İngiliz Hava Kuvvetleri'nin paraşütçülere destek verecek sahra toplarını taşımaya uygun nakliye uçakları yoktu. Bu yüzden paraşütçüler komutanların istediğinden daha küçük birlikler halinde tertiplenmişti. ${ }^{74}$

Ana çıkarma grubu ve saldırı gücü 6 Kasım'da Port Said'e ulaşmış ve kıyıya 5 mil mesafede demir atmış ve kıyıyı bombalamaya başlamıştır. Downing Street 10 numara (İngiliz Başbakanlık Konutu) sivil kayıpların

\footnotetext{
70 Keith Wheelock, Nasser's New Egypt, New York: Fredercik A. Praeger Publishers, 1960, s. 247.

${ }^{71}$ Birliğin 600 İngiliz, 500'ü ise Fransız paraşütçülerden oluşuyordu. (M.E.K.)

72 Love, a.g.m. , s. 576.

73 Rathburn, a.g.m.

74 H. P. Willmott, "The Suez Fiasco", Robert Thompson (Der.), War in Peace: Conventional and Guerilla Warfare Since 1945, Londra: Orbis, 1981 içinde s. 94 . Ayrıca bkz. R. W. Rathburn, a.g.m.
}

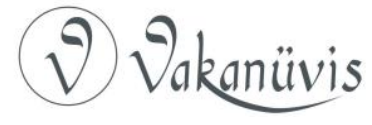


artmaması için bombardımanın durdurulması emrini vermesine rağmen Donanma Grup Komutanı yapılanın bombardıman değil destek atışı olduğunu ifade etmiş ve saldırıyı devam ettirmiştir. Topçu ateşinin bitmesinden sonra donanmaya bağı uçakların saldırısı başlamış ve çıkarma gemilerinin kıyıya kapak atmasından birkaç dakika öncesine kadar da aralıksız sürmüştür. Sabah 06:15'te ilk birlikler karaya çıkmıştır. 09:30'da ise Port Said'in güneyindeki ilk hedeflere ulaşılmıştır. Öğle üzeri de çıkartma birlikleri ile paraşütçüler birleşmiştir. Bu sırada takviyeler helikopterle gemilerden Port Said'e taşınmıştır. (415 asker ve 7 ton askeri malzeme) Ertesi gün, 7 Kasım'da çıkan fırtına ise denizden ikmali imkânsız kıldığı için ikmal yapılamamış ve ilerleyiş durmuştur.

\section{Süveyş Kanal Bölgesi'nin İşgalinin Sonuçları}

Silahşör/Musketeer Operasyonu sırasında uçak gemilerinden toplam 1.616 sorti yapılmıştır. (Harekatın yükünü çeken Sea Venom ve Sea Hawk uçakları günde ortalama 2,8 sorti ile en çok çıkış yapan uçaklar olmuştur.) İngilizler iki Sea Hawk, iki Wyvern ve bir Corsair uçağını düşman ateşi yüzünden kaybetmiştir. Bir Corsair pilotu da güvertede meydana gelen kazada ölmüştür. Müttefiklerin toplam kaybı 26 ölü ve 129 yaralıdır. $^{75}$

İngiliz ve Fransız kara birlikleri ateşkes ilan edilmeden önce mümkün olduğunca ilerleme emri aldıkları için ellerinden gelen her şeyi yapmıştır. Ama bu dönemde İngiliz ekonomisi savaştan çıktığı için oldukça güçsüzdür ve sıkıntılı günler geçirmektedir. Bu sıkıntısını atlatmak için ise IMF'den destek almaktadır. Fakat zaman zaman ihtiyaç duyduğu kredilerin serbest bırakılması için ABD'nin de onayı gerekmektedir. İngiltere'nin zayıf noktasını bulmuş olan Eisenhower bu türden bir onay vermeleri için İngiliz-Fransız ortak gücünün Mısır'ı boşaltması gerektiğini, bu şartları gerçekleşmeden kredi onayının verilmeyeceğini açıkça ifade etmiştir. Bu beyanat İngiltere'yi ve İngiliz kamuoyunu şok etmiş, İngilizler hazırlıksız yakalanmıştır. Fransa ise Ingilizlere göre daha rahattır: ABD'ye hiç güvenmedikleri için ihtiyaçları olan krediyi saldırıdan üç hafta önce almıştır. Bu hamle ile Eisenhower Ingilizlerden rövanşı almıştır. Eden müzakereler yoluyla ABD'den taviz

75 Love, a.g.e. , s. 635.

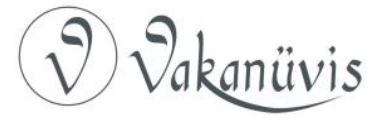


koparmaya ve Süveyş Kanalı ile ilgili planı tamamlamalarını sağlayacak zamanı kazanmaya çalışsa da başarılı olamamıştır. Özellikle İngiliz ekonomisinin çökmesi ihtimali onu her türlü şartı tartışmasız kabul etmeye mecbur bırakmıştır. ${ }^{76}$ Süveyş Krizi yüzünden Eden istifa etmek zorunda kalmış ve yerine Harold Macmillan geçmiştir. Macmillan ilk iş olarak ABD ile bozulmuş olan özel ilişkiyi tamir etmek için girişimlerde bulunmaya başlamıştır. Bu kararı ikili ilişkilerde önemli bir dönüm noktası olmuştur. Bu tarihten sonra İngiltere önemli dış politika girişimleri ve hamlelerinde Amerika ile istişare etmeden, onunla fikir alış verişi yapmadan adım atmamaya çalışmıştır. İngiltere açısından bu seferden çıkarılan dersler diğerlerininkine göre daha karmaşık ve komplekstir. Tüm operasyonlar tamamıyla eski ve demode olmuş ekipmanla yapılmıştır. İngiliz askeri başarısı, siyasi başarısızlık, iktisadi zayıflık ve istihbarat konusundaki öngörüsüzlük nedeniyle ciddi şekilde sınırlanmıştır. ${ }^{77}$ 20. yüzyılda yaşanan iki savaşta kademe kademe gerileyen İngiliz İmparatorluğu'nun dağıImasının başladığı olay Süveyş krizi olmuştur. ${ }^{78}$

Fransa açısından da krizin etkileri daha yıkıcıdır: Dördüncü Cumhuriyet sona ermiş ve ortaya çıkan siyasi kargaşa ancak Beşinci Cumhuriyet'in ilanı ve De Gaulle'ün başa geçmesi ile durulmuştur. Fransa bu olaydan sonra Avrupa'ya yakınlaşmayı seçmiş ve gerek Uzakdoğu gerekse de Süveyş krizi tecrübeleri nedeniyle bir daha asla Amerika'ya güvenmemiştir. ${ }^{79}$

$A B D$ de Süveyş krizinden kendi adına dersler çıkarmıştır. Bunun sonucunda $A B D$ yönetimi tecrübelerini Eisenhower Doktrini adı altında somutlaştırma yoluna gitmiş ve yazılı hale getirmiştir. 1957 Ocak ayında hazırlanan ve Mart ayında Kongre'nin onayından geçtikten

\footnotetext{
76 Thomas, a.g.e. , s. 149; Kunz, a.g.e. , s. 131-145; Chester L. Cooper, The Lion's Last Roar: Suez, 1956, Londra: Bodley Head, 1987, s. 192.

77 Rathburn, a.g.m.

78 "Ingiltere'nin yenilgisi siyasi ve diplomatik alanda idi." Rathburn, a.g.m.

79 Beaufire, a.g.e. , s. 14; Harold Macmillan, Riding the Storm, 1956-1958, New York: Harper and Row, 1971, s. 259; Niall Ferguson, Empire: The Rise and_Demise of the British World Order and the Lessons for Global Power, New York: Basic Books, 2003, s. 347; Tony Judt, Postwar: A History of Europe Since 1945, New York: Penguin, 2005, s. 298-299; Alistair Horne, La Belle France: A Short History, New York: Knopf, 2005, s. 387-388, 393-396 ve 397-404; Cooper, a.g.e. , s. 269 ve 275.
}

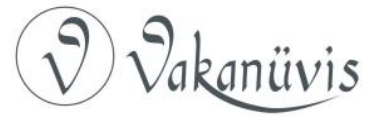


sonra yürürlüğe giren bu strateji $A B D$ 'nin Ortadoğu'yla olan ilişkilerini düzene sokmuş ve bölgeye askeri ve iktisadi yardım yapmanın şartlarını belirlemeye çalışmıştır. Ayrıca $A B D$, gerekli gördüğü hallerde bölgede ilerleme ve yayılma eğilimine giren Komünizm'i çevrelemek ve sınırlandırmak için askeri güç kullanma iradesini bir kez daha dile getirmiştir. ${ }^{80}$ Bir diğer önemli çıkarım da Süveyş Kanalı'nın durumunun nezaketi ve bu yüzden Ortadoğu petrollerine bağımlı olmak gerektiği olmuştur. Bu yüzden Amerika kendi rezervlerini kullanarak "Stratejik Petrol Rezervi"ni oluşturmuş ve enerji kaynağı tedarikçilerini çeşitlendirmeye çalışmıştır. Ayrıca ABD Basra Körfezi ve Ümit Burnu rotalarının güvenliği için Hint Okyanusu'nda daimi deniz gücü bulundurmasının gerekliliğine de ikna olmuştur. (ABD Beşinci Filosu bu sayede oluşturulmuştur. $)^{81}$

Süveyş Krizi sonucunda genelde Ortadoğu'da özelde ise Mısırda, Arap Milliyetçiliği ve Sömürgecilik-Batı karşıtlığı iyice güçlenmiştir. Süveyş Krizi, İngiltere ve Fransa'nın Arap ülkeleri nezdindeki prestijini ciddi şekilde sarsmıştır. ${ }^{82}$ Mısır, krizin askeri çatışmaya dönüştüğü kısmında iyi bir performans sergileyememiştir. Gerek kriz sırasında gerekse de kriz sonrasında Mısır'da ordu içinden kendine muhalif bir grup çıkmaması ve bir darbe ile devrilmemek için Nasır, ordunun eksikleri ve yetersizlikleri telafi etmekle ilgilenmemiş ve bunları telafi etmek için gereken ilgiyi göstermemiştir. Bunun sonucunda aynı durum daha sonra 1967 Altı Gün Savaşı'nda bir kez daha ama bu sefer daha büyük ölçekte tekrarlanmıştır. ${ }^{83}$ Fakat tüm bunlara rağmen Kanal'ın egemenliği ise Mısırda kalmaya devam etmiştir.

\section{Sonuç}

İkinci Dünya Savaşı sonrasındaki dönemde 19. Yüzyıl’ın büyük sömürge imparatorlukları ve onların kurmuş oldukları düzen dağılmış ve bir tarafta SSCB diğer taraf da ise ABD'nin önderliğini yaptığı iki kutuplu bir uluslararası siyasi yapı ortaya çıkmıştır. Bu yeni yapının ortaya çıkması eski düzenin tasfiyesini de beraberinde getirmiştir. Bu

\footnotetext{
${ }^{80}$ Hahn, a.g.m. , s. 29.

81 James D. Ladd, The Royal Marines, 1919-1980, Londra: Jane's Publishing Company Limited, 1980, s. 293-294.

82 Hahn, a.g.m. , s. 29.

${ }^{83}$ Rathburn, a.g.m.
}

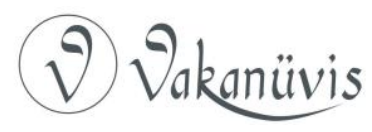


tasfiye sürecinde İngiltere kendi iktisadi, siyasi ve askeri yapısına ciddi bir yük olan sömürgelerini tahliye ve tasfiye etme yoluna gitmiştir. Ancak bu tasfiye esnasında tamamen eski sömürge bölgelerinden çekilmek yerine stratejik açıdan önemli noktaları, en azından Süveyş Kanalı'nın batısında kalanlarını elinde tutmayı gerekli görmüştür. Bilindiği üzere, bu çalışmanın da konusu olan Süveyş Kanalı bölgesi bu kilit önemdeki noktalardan biridir. 19. yüzyılın sonu ile 20. yüzyılın başındaki dönemde İngiliz İdaresi altında kalan ve bu yönetim dönemi ile ilgili ulusal onurunu rencide eden her şeyi unutmak isteyen Mısır, sömürge idaresi dönemini sürekli kendisine hatırlatan Süveyş Kanalı idaresini sonlandırmayı öncelikli amaç olarak seçmiştir. Bunda İngiltere ile yapılan ve Kanal bölgesinin tahliyesini öngören anlaşmanın da etkisi olmuştur. Mısır bu sayede rüştünü de ispat etmek ve Kanal'dan elde edilen gelirin desteği ile ülke refahını attıracak kalkınma projelerine girişmek amacında olmuştur. Ekonomik açıdan güçlenecek olan bir Mısır, Arap dünyasında da daha fazla söz sahibi olabilecektir. Bu yüzden Devlet Başkanı Cemal Abdünnasır'ın ortaya koyduğu ve sınırını çizdiği politikaları uygulamaya başlamışırı. Bu politikalar kapsamında öncelikle Arap dünyasının liderliği konusunda o dönemde yarıştığı Irak'ı Bağdat Paktı üyeliği üzerinden eleştirmiş ve itibarsızlaştırmaya çalışmıştır. Bu hamlesini Komünist grubun lideri SSCB ile ilişkilerini geliştirerek desteklemiştir. Ancak SSCB ile gelişen ilişkileri Batı tarafından pek de hoş karşılanmamıştır. SSCB konusunda yaptığı bu hamleye karşılık olarak Mısır, kendisine sağlanan maddi kaynaklardan mahrum bırakılarak terbiye edilmeye çalışılmıştır. Mısır'ın bu duruma tepkisi ise ülkenin sınırları içerisinde, sömürge döneminin canlı bir hatırası olarak duran Süveyş Kanalı'nı ve Kanalı işleten İngiliz-Fransız ortak şirketini millîleştirmek yönünde olmuştur. Bu yaptığı ile Mısır, Batılı eski idarecilerine artık eşit olduklarını, Arap dünyası ve Üçüncü Dünya ülkelerine ise aradıkları cesur ve örnek lider ülkenin kendisi olduğu mesajını vermeye çalışmıştır. Bu karardan Batı dünyasının lideri konumundaki $\mathrm{ABD}$ memnun olmamıştır. Ancak olası bir tepkisinin Mısır'ı Doğu Bloku'na yaklaştırmaması ve SSCB'nin Ortadoğu'ya müdahil olmasına ve etkisini attırmasına fırsat vermemesi için gerginliği büyütmemeye çalışmıştır. Bu kapsamda İngiltere-Fransa ikilisini de frenlemeye çalışmıştır. Ancak tüm girişimlere rağmen Ingiltere-Fransa ikilisi Süveyş kanalını yeniden ele geçirme ve Nasır'ı

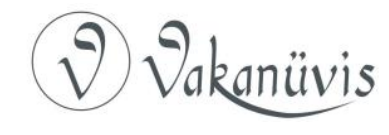


devirme planına devam etmiş̧ir. Bunun sonucunda da Süveyş Kanalı'ndaki durum önce krize, sonra da sıcak çatışmaya dönüşmüştür. Nasır ve Mısır çatışmanın topyekûn bir savaşa dönüşmemesi için sert bir direniş göstermemiştir. İngiltere-Fransa ikilisi askeri harekâtı kazanmış ama siyasi mücadeleyi kaybetmiştir. İngiltere bu olaydan kendi adına ciddi dersler çıkarmış ama Fransa olanlardan aynı derecede ders almamıştır. Benzer hataları ve aşırı şiddet içeren tutumunu Cezayir Bağımsızlık Savaşı sırasında da sergilemiştir. Fransa, Cezayir'de de askeri olarak kazanmış ama siyasi açıdan bir kez daha yenilmiştir. $\mathrm{Bu}$ kriz, Batı dünyasının lideri olarak yerini sağlamlaştırmaya çalışan ABD ile SSCB'yi ortak bir noktada buluşturmuştur. Iki yeni süper güç eski dönemin büyük devletlerinin yerini almak için bu krizi oldukça iyi değerlendirmiştir.

Süveyş Krizi daha sonraki yıllarda hemen her fırsatta yeniden canlanacak olan Türkiye ile Arap dünyası arasındaki güvensizlik ortamının da ortaya çıkmasına zemin hazırlamıştır. Arap dünyası, popülizmi seçmiş ve $A B D$ 'den gelen baskı ve Sovyetlerin toprak talebi sebebiyle oluşan gergin ortamda, Türkiye'nin İsrail'i tanımak zorunda kalmasını kendisine karşı takınılan düşmanca bir tutum olarak kabul etmeyi tercih etmiştir. Türkiye'nin $\mathrm{SSCB}^{\prime}$ den gelen tehdit yüzünden Bağdat Paktı'na katılması ise emperyalistlerle Araplara karşı komplo kurmak için işbirliğine gitmek şeklinde basitleştirilmiştir. Yine Süveyş Krizi esnasında Türkiye'nin Bağdat Paktı'nda çatlak oluşmaması için ittifak üyesi İngiltere hakkında açıklama yapmaması da olumsuz algıyı güçlendirmiştir. Bu duruma misilleme olarak ilk kez o dönemde uluslararası gündeme taşınan Kıbrıs konusunda Türkiye yalnız kalmıştır. Araplar Yunanistan'ı desteklemekte beis görmemiştir. Hatta 1957 yılında BM konu ile ilgili yapılan görüşmelerde Bağdat Paktı üyesi Irak dahi Türkiye aleyhine oy kullanmıştır. Bu da Türk kamuoyu ve yönetici eliti arasında Araplara güvenilemeyeceği algısını kuvvetlendirmiştir. Bozulan ilişkileri iyileştirmek isteyen Türkiye, 1960 'ı yıllardan itibaren Arap dünyası ile yakınlaşmaya çalışmış ancak bu girişimlerinde beklenen karşıı̆̆ı görmemiştir. Arap dünyasının olumsuz tavrı ön yargıları güçlendirmiş ve Türkiye içinde belli bir kesimde kırgınlığa yol açmıştır. İşte bu süreci başlatan olaylardan birisi de 1956 Süveyş Krizi olmuştur.

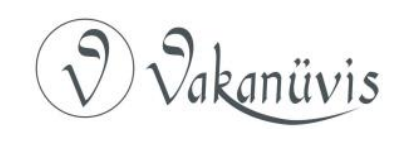




\section{Kaynaklar}

Armaoğlu, Fahir, 20 Yüzyıl Siyasi Tarihi 1914-1980, Ankara: Türkiye iş̧ Bankası Kültür Yayınları, 1983.

Armaoğlu, Fahir, Filistin Meselesi ve Arap israil Savaşları 1948-1988, Ankara: Türkiye İş Bankası Kültür Yayınları, 1991.

Aydemir, Şevket Süreyya, Asvan Barajı Problemi, Ortadoğu, Cilt: 1, Sayı: 4, (1961), s. 9-12.

Beaufre, André, The Suez Expedition 1956, Londra: Faber and Faber 1969.

Beschloss, Michael R., Mayday: Eisenhower, Khruschev and the U-2 Affair, New York: Harper and Row, 1986.

Binder, Leonard, The Ideological Revolution in the Middle East, New York: Wiley\&Sons Inc., 1964.

Calvocoressi, Peter, World Politics since 1945, Londra: Longman Group UK Limited, 1987.

Coles, Michael H., "Suez, 1956-A Successful Naval Operation Compromised by Inept Political Leadership", Naval War College Review, Cilt: 59, Sayı: 4, (2006), s. 100-118.

Cooper, Chester L., The Lion's Last Roar: Suez, 1956, Londra: Bodley Head, 1987.

Cull, Brian, Nicolle, David ve Aloni, Shlomo, Wings Over Suez: Air Operations During the Sinai and Suez Wars of 1956, Londra: Grub Street, 1996.

Dayan, Moshe, Diary of Sinai Campaign, New York: Schocken Books, 1967.

Duman, Sabit, Ortadoğu Krizleri ve Türkiye, Ankara Üniversitesi Türk Inkilap Tarihi Enstitüsü Atatürk Yolu Dergisi, Sayı: 35-36, (2005), s. 313-332.

Ferguson, Niall, Empire: The Rise and_Demise of the British World Order and the Lessons for Global Power, New York: Basic Books, 2003.

Freidman, Norman, British Carrier Aviation: The Evolution of the Ships and Their Aircraft, Annapolis: Naval Institute Press, 1989.

Gaddis, Lewis, We Now Know: Rethinking Coldwar History, New York: Oxford University Press, 1997.

Gökdeniz, Sermet, "1956 Süveyş Kanalı Buhranı ve Port Sait Harekâtı", Donanma Dergisi, Cilt: 71, Sayı: 426, (1959), s. 1-35.

Gorst, Anthony ve Johnman, Lewis, The Suez Crisis, New York: Routledge, 1997.

Gönlübol, Mehmet vd., Olaylarla Türk Dış Politikası (1919-1995), Ankara: Siyasal Kitabevi, 1996.

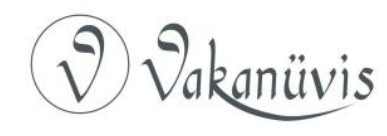


Gray, Ellen, "Blind Loyalty? The Menzies Mission to Cairo During the 1956 Suez Canal Crisis", Diplomacy\&Statecraft, Cilt: 32, Sayı: 4, (2021), s. 86-113.

Grogin, Robert C., Natural Enemies, The United States and the Soviet Union in the Cold War 1917-1991, Lenham-Maryland: Lexington Books, 2001.

Groove, Eric, Vanguard to Trident: British Naval Policy Since World War II, Londra: Bodley Head, 1987.

Hahn, Peter L., The Suez Crisis, A Crisis That Changed the Balance of Power in the Middle East, Significant Events in U. S. Foreign Relations, 1900-2001, Foreign Policy Agenda, ejournalusa, U. S. Department of State/Bureau of International Informations Programs, Cilt: 11, Sayı: 1,(Nisan 2006) Washington, s. 26-29.

Hart, Larry, "Failures in American Diplomacy: The Suez Crisis, 1956", History Studies, Cilt: 3, ABD ve Büyük Ortadoğu İlişkileri Özel Sayısı 2011, s. 157-168.

Horne, Alistair, La Belle France: A Short History, New York: Knopf, 2005.

Jackson, William Godfrey Fothergill, ve Bramall, Dwin, The Chiefs: The Story of the United Kingdom Chiefs of Staff, Londra: Brasseys's, 1992.

Judt, Tony, Postwar: A History of Europe Since 1945, New York: Penguin, 2005.

Kyle, Keith, Suez: The Twice Fought War, New York: McGraw-Hill, 1969.

Kyle, Keith, Suez, New York: St. Martin's, 1991.

Kunz, Diane B., The Economic Diplomacy of the Suez Crisis, Chapel Hill: University of North Carolina Press, 1991.

Ladd, James D., The Royal Marines, 1919-1980, Londra: Jane's Publishing Company Limited, 1980.

Love, Kennett, Suez, The Twice Fought War, New York: McGraw-Hill Book Company, 1968.

Macmillan, Harold, Riding the Storm, 1956-1958, New York: Harper and Row, 1971.

Mansfield, Peter, Osmanlı Sonrası Türkiye ve Arap Dünyası, Çev. Nuran Ülken, İstanbul: Sander Yayınları, 1975.

Mosley, Leonard, Dulles: A Biography of Eleanor, Allen and John Foster Dulles and Their Family Network, New York: Hodder and Stoughton 1978.

Murphy, Robert, Diplomat Among Warriors, New York: Doubleday, 1964.

Neff, Donald, Warriors at Suez, New York: Simon and Schuster, 1981.

Nutting, Anthony, No Ends of a Lesson, The Story of Suez, New York: Clarkson N. Potter, 1967.

Rathburn, R. W., Operation Musketeer: A Military Success Ends in Political Failure, Marine Corps Command and Staff College, Marine Corps Development and Education Command, War Since 1945 Seminar, Quantico

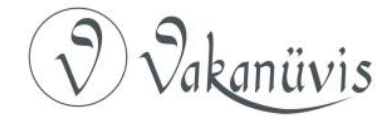


Virginia:

2

Nisan

1984,

http://www.globalsecurity.org/military/library/report/1984/RRW.htm

(Erişim tarihi: 07.09.2018)

Serbest, Bürkan, “Süveyş Kanalı’nın Ulusallaştırılması Sorunu ve Süveyş Bunalımı", Manas Sosyal Araştırmalar Dergisi, Cilt: 6, Sayı: 4, (2017), s. 689711.

Sharabi, Hisham, Goverments and Politics of the Middle East Twentieth Century, Princeton-New Jersey: D. Van Nostrand Company Inc. 1962.

Taşhan, Seyfi, "Petrol İhtiyaçlar, Buhranlar ve Politikalar", Dış PolitikaForeign Policy, Cilt: 3, Sayı: 2, (1973), s. 11-31.

The Suez Crisis, 1956, Washington: The Office of the Historian, Foreign Relations of the United States, U. S. State Department, 1990 (FRUS).

Thomas, Hugh, Suez, New York: Harper and Row, 1967.

Wheelock, Keith, Nasser's New Egypt, New York: Fredercik A. Praeger Publishers, 1960.

Willmott, H.P., "The Suez Fiasco", Robert Thompson (Der.), War in Peace: Conventional and Guerilla Warfare Since 1945, Londra: Orbis, 1981.

Wright, William M., Shupe, Michael C., Fraser, Niall M. ve Hipel, Keith W., "A Conflict Analysis of the Suez Canal Invasion of 1956", Conflict Management and Peace Science, Cilt: 5, Sayı: 1, 1980, s. 27-40. 